\title{
Variability properties of daily and monthly observed near-surface temperatures in Uganda: 1960 to 2008
}

1. Francis Wasswa Nsubuga

Department of Geography, Geoinformatics and Meteorology

Center for Environment Studies

University of Pretoria.

Pretoria 0002 . RSA

E-mail: nwasswa@gmail.com

2. Jane Mukarugwiza Olwoch $(\mathrm{PhD})$

Department of Geography, Geoinformatics and Meteorology

University of Pretoria.

Pretoria 0002 . RSA

E-mail: jane.olwoch@up.ac.za

3. Hannes Rautenbach, C.J.deW. (Prof.)

Department of Geography, Geoinformatics and Meteorology

University of Pretoria.

Pretoria 0002. RSA

E-mail: hannes.rautenbach@up.ac.za

\begin{abstract}
Variability and trends in daily and monthly near-surface temperatures in Uganda, collected over the period 1960 to 2008 (49 years), are analyzed. For this purpose daily observational temperature records from eight selected stations in Uganda were acquired from the Uganda Meteorological Department (UMD). Data collected by the UMD are quality controlled through a rigorous process before being archived. The data received were tested for homogeneity, gaps were filled and simple correlation analyses were used for validation during the analysis. Statistical techniques (Mann-Kendall and linear regression) were employed to analyze temperature variability and to obtain temperature trends. Findings indicate that intra-annual temperature shows reduced variability over recent decades, but which is not statistically significant. An examination of intra-monthly trends in daily maximum and minimum
\end{abstract}


temperatures revealed a general decline of intra-annual variance of monthly temperature means. Results also demonstrated that maximum temperatures are more variable compared to minimum temperatures in Uganda. An increasing trend in hot days, hot nights, warm nights and warm spells were also detected. At seven of the stations, annual temperature range and diurnal temperature range trends were found to be negative. The finding that intra-annual and intramonthly variance is declining suggests that fewer anomalously extreme temperature episodes occur. The gap between maximum and minimum extremes is reducing, which supports the observation that minimum temperatures are on the increase

Key words: Uganda, climate change, Mann-Kendall test, trend analysis, temperature variability.

\section{Introduction}

The climate science community agrees that changes in the frequency and intensity of climate events are likely to impact nature and society in future (Zhang et al, 2005; Easterling et al, 2003). Unfortunately, such changes are not well documented for some parts of the world, which raises concern amongst scientists, (Easterling et al., 2003; Mahli and Wright, 2004; New et al., 2006; Thornton et al., 2007). This is despite of the anticipation that climate change might have a profound effect on developing countries, of which many are located in Africa. Some studies that have documented changes in climate and climate variability and their impacts for Africa include: New et al., (2006); Kruger and Shongwe, (2004); Mahe et al., (2001); King'uyu et al., (2000), amongst others. The few regional studies conducted in Africa revealed that observed changes in climate are not spatially uniform (Kizza et al., 2009; Mubiru et al., 2009; Schreck and Semazzi, 2004; Nicholson, 1996; Basalirwa, 1995; Ogallo, 1993; Rodhe and Virji, 1976 and Samson, 1952) because of geographical and land-surface variations. Nevertheless, profiling these changes has enhanced the understanding of climate in the continent, and contributed to more informed decisions on, and respondes to, climate change.

Studies on near-surface temperature changes conducted in Africa, and elsewhere in the world, have demonstrated that it is important to study temperature trends at a regional level. Such regional studies are more detailed and bring out differences between a specific region and the 
wider surrounding area. For example, various studies (Kafle and Bruins, 2009; S.del Rio et al., 2007; Cheema et al, 2006; Domroes and El-Tantawi 2005; Kruger and Shongwe, 2004) have identified climate characteristics that are unique to a particular country. These studies have not only informed the scientific community about the climate characteristics of a region, but also formed the baseline for future studies. In general, trend results obtained from annual as well as minimum and maximum temperatures for Africa agrees with international findings on global warming. However, more studies are required for such trends in equatorial locations.

Like most other African countries Uganda has decided to prioritize climate change because of the anticipated impact that it might have in future on livelihoods and social society (GOU, 2002; NEMA, 2008). In Uganda there are already noticeable observed changes in weather patterns, for example more erratic rainfall in the March to June rainy season which coincides with drought and a subsequent reduction in crop yield. It is also found that rains towards the end of the year are becoming more intense and destructive, bringing floods, landslide and soil erosion (Oxfam, 2008). These recent climatic changes are already negatively impacting sustainable food security. Women are found to be most affected, which hampers their effort to overcome poverty (Oxfam, 2008).

A detailed study on near-surface temperature variability and trends in Uganda has not yet been carried out, especially to include recent global temperature increases since the 1970s. A primary motivation for undertaking this study was therefore to investigate temperature trends in Uganda during the more recent decades when the global warming signal has intensified consistently, compared to previous decades. The aim of the study is to explore the variation of, and to try and identify trends in near-surface temperatures, and in particular maximum temperatures $\left(T_{\max }\right)$ and minimum temperatures $\left(\mathrm{T}_{\min }\right)$ in Uganda by means of a detailed statistical analysis of data gathered at eight meteorological stations over a 49-year period (1960 to 2008). Temporal analyses have been carried out at intra-annual time scales (daily and monthly) using minimums of minimum temperatures $\left(\mathrm{mnT}_{\min }\right)$, maximums of minimum temperatures $\left(\mathrm{mxT}_{\min }\right)$, maximum of maximum temperatures $\left(\mathrm{mxT}_{\max }\right)$, minimum of maximum temperatures $\left(\mathrm{mnT}_{\max }\right)$. In addition time series of Diurnal Temperature Range (DTR) and Annual Temperature Range (ATR) have also been analyzed. 
The study further attempts to document extreme temperature events using a suite of indices. These indices are an outcome from a joint effort by the World Meteorological Organization (WMO) CCI/CLIVAR/JCOMM Expert Team on Climate Change Detection, Monitoring and Indices (ETCCDMI) (Zhang et al., 2005).

\section{DATA AND METHODOLOGY}

\subsection{Study area}

As illustrated in figure 1, Uganda is located in the east African equatorial area between $1^{0} \mathrm{~S}$ to $4^{0} \mathrm{~N}$ and $29^{0} \mathrm{E}$ to $35^{\circ} \mathrm{E}$ (Mubiru et al, 2009). The location of the eight temperature stations used in this study is also denoted in figure 1. Uganda is the smallest of the three east African republics, with an estimated population, according to the Uganda Bureau of Statistics 2009), of 33 million people.

According to Köppen's climate classification, Uganda experiences a tropical moist climate, where all months have an average temperature of greater than $18^{0} \mathrm{C}$ and an annual precipitation of greater than $1500 \mathrm{~mm}$ (Griffiths, 1972). Monthly average temperatures in Uganda vary from $24^{\circ} \mathrm{C}$ to $30^{\circ} \mathrm{C}$, while the annual range of temperature is about $3^{\circ} \mathrm{C}$. The annual variation of mean monthly air temperature is very small, usually $1^{0}$ to $2^{0} \mathrm{C}$ in the south-west of Uganda and the south-western part of Lake Victoria. 


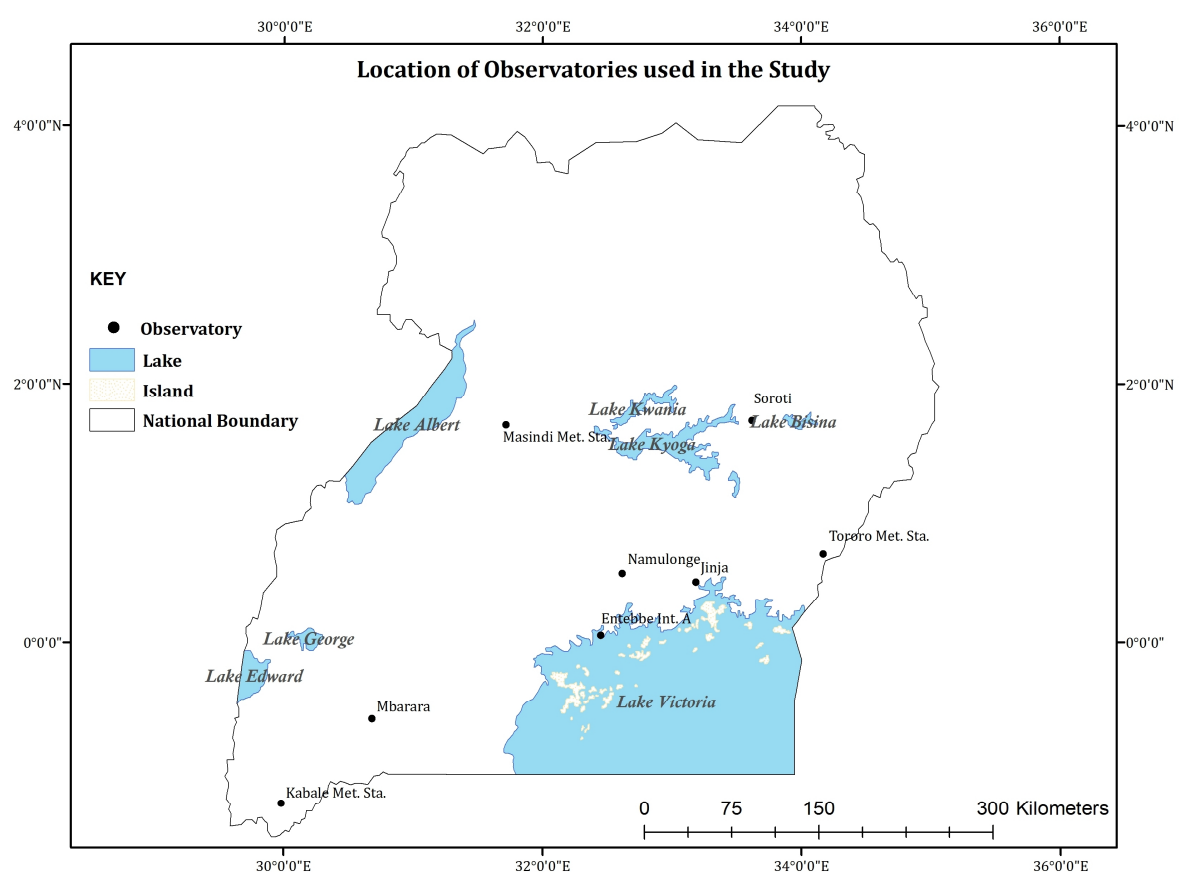

Figure 1 A map of Uganda, which is located in equatorial Africa, with its lakes and lake islands. The locations of the eight near-surface temperature recording weather stations used in this study are depicted by black circles.

Details of the climatic systems that modulate the space-time characteristics of rainfall and temperature over east Africa have been elaborated on in previous studies (Phillips and Mcintyre, 2000; Ogallo, 1993). On a more local scale, Kizza et al. (2009), Anyah and Semazzi (2009) and Anyah and Semazzi (2004) recently shed more light on the general circulation and the general climatology of Lake Victoria, which has a significant influence on Uganda's climate. In general, the location of Uganda astride the equator exposes it to comprehensive sunshine associated with high temperatures and rainfall.

\subsection{Temperature data}

The near-surface temperature data used in this study were provided by the Uganda Meteorological Department (UMD) in the Ministry of Water and Environment, Kampala, where collected data are entered and archived using the Climate-Computing (CLICOM) format. Here the data goes through a rigorous process to ensure that stored data are of an highly acceptable quality. Data from eight temperature recording stations were selected (figure 1), taking into account the length and availability of data records. The eight stations are fairly well distributed 
across the country and cover three regions, namely, eastern, western and central Uganda (Basalirwa, 1995). Daily temperature records were used to generate monthly and annual means of $\mathrm{T}_{\max }$ and $\mathrm{T}_{\min }$ at each station. Temperature records that were used meet the WMO required climatological record length of at least 30-years (table 1).

Table 1 List of the eight near-surface temperature weather stations that were used in this study. Note that these stations are located in different climate zones all across Uganda.

\begin{tabular}{|l|l|l|l|l|l|}
\hline Station Name & $\begin{array}{l}\text { Station ID/ } \\
\text { Code }\end{array}$ & Longitude & Latitude & $\begin{array}{l}\text { Altitude } \\
\text { (meters) }\end{array}$ & Record length \\
\hline $\begin{array}{l}\text { Entebbe International } \\
\text { Airport }\end{array}$ & 89320660 & $32^{0} 45^{\prime} \mathrm{E}$ & $0^{0} 05^{\prime} \mathrm{N}$ & 1155 & $1960-2009$ \\
\hline Jinja & 89330430 & $33^{0} 18^{\prime} \mathrm{E}$ & $0^{0} 45^{\prime} \mathrm{N}$ & 1175 & $1960-2000$ \\
\hline Mbarara & 90300030 & $30^{0} 68^{\prime} \mathrm{E}$ & $0^{0} 6^{\prime} \mathrm{S}$ & 1420 & $1960-2008$ \\
\hline Namulonge & 89320670 & $32^{0} 61^{\prime} \mathrm{E}$ & $0^{0} 5^{\prime} \mathrm{N}$ & 1130 & $1953-2008$ \\
\hline Kabale & 91290000 & $29^{0} 59^{\prime} \mathrm{E}$ & $1^{0} 15^{\prime} \mathrm{S}$ & 1869 & $1960-2000$ \\
\hline Masindi & 88310030 & $31^{0} 72^{\prime} \mathrm{E}$ & $1^{0} 68^{\prime} \mathrm{N}$ & 1147 & $1965-2000$ \\
\hline Soroti & 88330060 & $33^{0} 37^{\prime} \mathrm{E}$ & $1^{0} 43^{\prime} \mathrm{N}$ & 1132 & $1971-2000$ \\
\hline Tororo & 89340190 & $34^{0} 10^{\prime} \mathrm{E}$ & $0^{0} 41^{\prime} \mathrm{N}$ & 1170 & $1961-1996$ \\
\hline
\end{tabular}

\subsubsection{Processing of data}

The key outcome for processing the near-surface temperature data was to detect whether trends in temperature are present in the data records. A trend depicts a consistent long-term change in a time series, which could be identified by the use of either graphical tools or statistical methods (Longobardi and Villani, 2010). There are many methods for identifying trends in literature (e.g. Samson, 1952; Piccarreta et al., 2004; Ghahraman \& Taghvaeian, 2008; Caloiera et al., 2009; Lopez-Moreno et al., 2009). In this study graphical and statistical approaches are combined in an effort to identify statistically significant trends in the temperature of Uganda, since it is known that a combination of approaches could yield more information on trends (del Rio et al., 2007). 


\subsection{Data limitations}

Data used in the study were characterized by the following limitations: (1) Metadata required for homogeneity testing were totally absent. The absence of metadata was a determinant in choosing absolute tests against the more popular relative testing as a method of testing for inhomogeneities. (2) Not all stations had the same data collecting period and some gaps occurred in the data. Both these problems were addressed as discussed below.2.5 Homogeneity testing

Trend analysis are limited by the degree of inhomogeneity in data (Aguilar et al. ,2003). It is important to note that homogeneities in climatic data manifest itself in two ways: (1) as a gradual trend or (2) as a discontinuity (sharp change) in the mean or variance (Easterling et al., 1996). There are numerous methods to use in evaluating homogeneity in daily to monthly temporal climate data (Peterson et al., 1998). This study restricts the homogeneity analysis to absolute tests and relies on four statistical methods, namely: (1) Von Neumann ratios (Sahin and Cigizoglu, 2010; Lima et al., 2010); (2) Cumulative deviations; (3) Worsely's likelihood ratio tests (Pandžić and Lisko, 2009) and (4) Bayesian procedures. These tests are well defined in Buishand (1982), and the detailed mathematical formulation of the tests is also discussed in Wijngaard et al (2003). The tests were applied on DTR time series, because they are strong indicators of the degree of climate variability and change (S.del Rio et al., 2007). Lucio et al., (2007) also reiterates that inhomogeneity most clearly appear in DTR time series.

\subsection{Estimating data gaps}

A study by Stooksbury et al. (1999) on the effects of data gaps, as a result of missing data, demonstrated that monthly mean $\mathrm{T}_{\max }$ and $\mathrm{T}_{\min }$ values could differ by more than $\pm 1{ }^{0} \mathrm{C}$ with only a 3-day gap in the data. It is also mentioned in the same study that data of regions that have daily persistence in temperatures are least impacted by data gaps. Uganda is located in the equatorial region of Africa where daily persistence in temperatures is experienced, implying that gaps would therefore have a smaller impact on data analysis. With climate variability and climate trend analyses, data gaps are especially a concern when they occur early or late in the data record, which was not the case for the temperature data used in this study. A number of methods may be 
used to produce estimated values for data in these gaps, such as the substitution of the nearest neighbor value, the Kriging method, using a derived value or by using the mean value to fill missing data (Jones et al., 1999). In this study gaps in the data could not be ignored because the software used for analysis required continuous data. Gaps were therefore filled using long-term daily mean values of a particular month at a particular station. Fortunately, by applying this method the mean value (and trend) of the data was not affected, but it rather ensured that data were continuous.

\subsection{Calculation of intra-annual temperature variance}

The variability of intra-annual monthly $T_{\max }$ and $T_{\min }$ values, as well as area averages of temperatures, were analyzed in this study. These thermometric variables have raised interests amongst scientists like Braganza et al. (2004) who argued that changes in mean surface temperature could be due to changes in $\mathrm{T}_{\max }$ and $\mathrm{T}_{\min }$ values, or both S.del Rio et al (2007). Monthly mean $\mathrm{T}_{\max }$ and $\mathrm{T}_{\min }$ values were therefore derived from daily data. These data series contained a complete set of 12 monthly means for each year under consideration, from where the intra-annual variance in temperature was calculated for each year (Micheals et al., 1998):

$$
\text { Variance }=\frac{\sum_{i=1}^{n}\left(T_{i}-\bar{T}\right)^{2}}{n-1}
$$

where $T_{i}$ is the mean temperature for month $i, \bar{T}$ the long-term mean temperature, and $n$ is the number of months per year (equal to 12 ).

\subsection{Test for trends on temperature indices}

The indices used in the study are part of the 27 set of indices, elaborated on in the introduction. These indices have been computed before for other regions (Easterling et al., 2003; New et al., 2006). In this study however, only those indices shown in (table 2), considered to be relevant for the region have been analysed using excel and trend software package. 
Table 2. Temperature Indices analysed for trend on annual data of Uganda.

\begin{tabular}{|c|c|c|}
\hline Descriptive Name & Definition & Units \\
\hline Hot days & Annual count when maximum temperature $>25^{\circ} \mathrm{c}$ & Days \\
\hline Warm nights & Annual count when minimum temperature $>20^{\circ} \mathrm{c}$ & Days \\
\hline Hottest day & Monthly highest maximum temperature & ${ }^{0} \mathrm{C}$ \\
\hline Hottest night & Monthly highest minimum temperature & ${ }^{0} \mathrm{C}$ \\
\hline Coolest day & Monthly lowest maximum temperature & ${ }^{0} \mathrm{C}$ \\
\hline Coolest night & Monthly lowest minimum temperature & ${ }^{0} \mathrm{C}$ \\
\hline Cool night frequency & $\begin{array}{l}\text { Percentage of days when minimum temperature }<10^{\text {th }} \text { percentile } \\
\text { of the (period) }\end{array}$ & $\%$ \\
\hline Cool day frequency & $\begin{array}{l}\text { Percentage of days when maximum temperature }<10^{\text {th }} \text { percentile } \\
\text { of the (period) }\end{array}$ & $\%$ \\
\hline Hot day frequency & $\begin{array}{l}\text { Percentage of days when maximum temperature }>90^{\text {th }} \text { percentile } \\
\text { of the (period) }\end{array}$ & $\%$ \\
\hline Hot night frequency & $\begin{array}{l}\text { Percentage of nights when maximum temperature }>90^{\text {th }} \text { percentile } \\
\text { of the (period) }\end{array}$ & $\%$ \\
\hline Warm spell & $\begin{array}{l}\text { Annual count of days with at least } 6 \text { consecutive days when } \\
\text { maximum temperature }>90^{\text {th }} \text { percentile (period) }\end{array}$ & Days \\
\hline $\begin{array}{l}\text { Diurnal temperature range } \\
\text { (DTR) }\end{array}$ & $\begin{array}{l}\text { Monthly mean difference between maximum temperature \& } \\
\text { minimum temperature. }\end{array}$ & ${ }^{0} \mathrm{C}$ \\
\hline $\begin{array}{l}\text { Annual temperature range } \\
\text { (ATR) }\end{array}$ & $\begin{array}{l}\text { Difference between maximum temperature maximums and } \\
\text { minimum temperature minimum. }\end{array}$ & ${ }^{0} \mathrm{C}$ \\
\hline
\end{tabular}

\subsection{Construction of Area average temperature series}

The Construction of an area average station temperature series is aimed at providing an overall picture of temperature variation in the central and southern part of the Uganda. Original monthly temperature series were converted to standardized monthly series $\left(\mathrm{M}_{\mathrm{sy}}\right)$ by subtracting the long term mean $\left(\overline{R_{s}}\right)$ from the original monthly values $\left(R_{s y}\right)$ and then to divide the result by standard deviation $\left(\sigma_{s}\right)$ at each station. This process minimizes the problem of highly diverse means and variability and the randomness of station totals (Nicholson1986). The normalized temperature anomaly for a given station is:

$$
M_{s y}=\left(R_{s y}-\overline{R_{s}}\right) / \sigma_{s}
$$


The area-averaged (regional mean climatology) normalized monthly temperature anomaly $\left(M_{r y}\right)$ for a given region is defined as:

$$
M_{r y}=\left(1 / N_{j}\right) \sum_{s=1}^{N_{s}} M_{s y}
$$

where $N_{j}$ is the number of regional stations for the year $j$. The use of regional average, in general, provides a time series that is a better representation of large-scale climatic processes (Partal and Kahya, 2006), thus making it easier to deal with one index series in a region.

Before using the $M_{r y}$ series with confidence for the discussion and analysis of regional monthto-month and year-to-year fluctuations, it has to be demonstrated that it is indeed representative for the region as a whole (Kraus, 1977; Nicholson, 1986; Türkeş, 1996). The validity of the regionalization for all series is tested using correlation coefficients. Like Nicholson (1986), any station correlating at less than 0.4 with the regional series is dropped and the regional series is recalculated, omitting data for that station.

Effects of errors and lack of consistency at individual stations often reduces when averaging data to calculate regional area series (S.del Rio et al., 2007; Jones et al., 1999). Homogeneity tests were applied on both station series and the area average series as discussed in section 3.1 above.

\subsection{Trend analysis}

Trends have been analysed using both parametric and non-parametric tests. The Mann-Kendall (MK) is a non-parametric method, which tests whether there is a trend in the time series including climatic data $(\mathrm{CRCCH}, 2005)$. The $n$ time series values $\left(\mathrm{X}_{1}, \mathrm{X}_{2}, \mathrm{X}_{3}, \ldots . \mathrm{X}_{\mathrm{n}}\right)$ are replaced by their relative ranks $\left(\mathrm{R}_{1}, \mathrm{R}_{2}, \mathrm{R}_{3}, \ldots, \mathrm{R}_{\mathrm{n}}\right)$ (starting at 1 for the lowest up to $n$ ). The test statistic $S$ is:

$$
S=\sum_{i=1}^{n-1}\left[\sum_{j=i+1}^{n} \operatorname{sgn}\left(R_{j}-R_{i}\right)\right]
$$


Where

$$
\begin{aligned}
& \operatorname{sgn}(x)=1 \text { for } x>0 \\
& \operatorname{sgn}(x)=0 \text { for } x=0 \\
& \operatorname{sgn}(x)=-1 \text { for } x<0
\end{aligned}
$$

If the null hypothesis $\mathrm{H}_{\mathrm{o}}$ is true, then $S$ is approximately normally distributed with:

$$
\begin{aligned}
& \mu=0 \\
& \sigma=n(n-1)(2 n+5) / 18
\end{aligned}
$$

The $Z$ - statistic is therefore (critical test statistic values for various significance levels can be obtained from normal probability tables):

$$
Z=|\mathbf{s}| / \sigma^{0.5}
$$

A positive value of $s$ indicates that there is an increasing trend and vice versa. The null hypothesis $\mathrm{H}_{\mathrm{o}}$ assuming that there is no trend in the data is either accepted or rejected if the computed $Z_{\mathrm{s}}$ statistics is less than or more than the critical value of the $Z$-statistics obtained from the normal distribution table (Kampata et al., 2008). Significance levels used in the study are $0.01,0.05$ and 0.10 . The $M K$ statistics has the advantage of making no assumptions about the statistical distribution of variables (Mahli and Wright, 2004).

For the purpose of cross verification a trend was also indentified using the Linear Regression test. It tests whether there is a linear trend by examining the relationship between time $(x)$ and the variable of interest $(y)$. The regression gradient is estimated by $(\mathrm{CRCCH}, 2005)$ :

$$
b=\frac{\sum_{i=1}^{n}\left(x_{i}-\bar{x}\right)\left(y_{i}-\bar{y}\right)}{\sum_{i=1}^{n}\left(x_{i}-\bar{x}\right)^{2}}
$$

And the intercept is estimated as:

$$
a=\bar{y}-b \bar{x}
$$

The test statistic $\mathrm{S}$ is:

$$
\begin{gathered}
\mathrm{S}=\mathrm{b} / \sigma \\
\text { Where } \sigma=\sqrt{\frac{12 \sum_{i=1}^{n}\left(y_{i}-a-b x_{i}\right)}{n(n-2)\left(n^{2}-1\right)}}
\end{gathered}
$$


The test statistic $S$ follows a student $-t$ distribution with n-2 degrees of freedom under the null hypothesis (critical test values for various significance levels can be obtained from student's $t$ statistic tables). The linear regression test assumes that the data are normally distributed and that the errors (deviations from the trend) are independent and follows the same normal distribution with zero mean. Data was tested for normality using a normal probability plot (Chambers, 1983). This is a graphical technique for assessing whether or not a data set is approximately normally distributed. Data are plotted against a theoretical normal distribution in such a way that the points should form an approximate straight line. Departures from this line indicate departures from normality. Plots indicated that data points nearly form a linear pattern, implying a normal distribution (plots not shown)making the series suitable for a linear regression trend analysis.

\section{Results and discussions}

\subsection{Homogeneity test of station DTR series.}

Homogeneity test results show that, all eight stations used in the study have experienced statistically significant step jumps in their DTR series. Six of the stations showed strong evidence against the $\mathrm{H}_{\mathrm{o}}$ (no change) at a $<0.01$. They include Entebbe, Mbarara, Namulonge, Soroti, Tororo and Kabale. Jinja station DTR series indicate a significant change at 5\% significant level, whereas DTR series at Masindi station show a step jump which is not statistically significant at $\mathrm{a}=0.10$. Another outcome of the analysis is that both cumulative deviations and Worsely likelihood tests detected change points at around the same years at almost all stations, except for Masindi which showed a big difference (not shown). All the four tests lead us to a conclusion that the series were not homogeneous and therefore, had experienced significant changes.

\subsection{Intra-annual variance in $\mathrm{MxT}_{\max }$ and $\mathrm{MnT}_{\min }$ station temperatures}

Analysis of station temperature reveals that, trend of $\mathrm{mxT}_{\max }$ for Namulonge station is decreasing $(-0.03)$, while a station like Entebbe depicts an increasing trend $(0.70)$, in the respective period 
of analysis and both are statistically significant. In contrast Entebbe has decreasing $\mathrm{mn}_{\min }(-0.02)$, which is significant (table 3). Majority of the stations which include; Mbarara, Entebbe, Namulonge, Jinja, Kabale and Masindi reveal that $\mathrm{mxT}_{\max }$, have varied more in the period of analysis compared to what has been experienced in Soroti and Tororo. Great variability in $\mathrm{mnT}_{\min }$ is also experienced in Namulonge, Soroti, Entebbe, Jinja, Mbarara, Masindi and Tororo (table 3). In comparison to temperatures observed at the rest of the stations, $\mathrm{mxT}_{\max }$ in Soroti are less varied $(32 \%)$ but, at the same time Soroti exhibits high variability in $\mathrm{mnT}_{\min }(121 \%)$. And Kabale has the lowest of the $\mathrm{CV}$ in its $\mathrm{MnT}_{\min }(42 \%)$. Overall, Tororo has the lowest variability in its temperature variables.

The study did not venture into finding out the reasons behind this kind of temperature behavior. There is a possibility that, the trend of temperatures observed at Entebbe and Namulonge stations could be attributed to their location (figure 1), intense human activities and influence of urbanization which have modified the local terrain. The study also reveals that, in their second normal, Entebbe, Jinja and Mbarara have experienced more variation in $\mathrm{mxT}_{\max }$. More variation has also happened within the $\mathrm{mnT}_{\min }$ of Entebbe, Jinja, Namulonge and Tororo (table 3). The area average series pattern also demonstrates a general decline of the within-year variance of the monthly temperature means (table 3).

Table 3. Showing linear trend, determination coefficient $\left(\mathrm{R}^{2}\right)$ and coefficient of variance (CV), for maximums of temperature maximum and minimums of temperature minimum for station and area average series in Uganda.

\begin{tabular}{|c|c|c|c|c|c|c|c|}
\hline \multirow[t]{2}{*}{$\begin{array}{l}\text { Meteorological } \\
\text { Station } \\
\text { Name }\end{array}$} & \multirow[t]{2}{*}{$\begin{array}{ll}\text { Period } & \text { of } \\
\text { analysis } & \end{array}$} & \multicolumn{3}{|c|}{$\begin{array}{l}\text { Maximums of } \\
\text { Temperature } \\
\left.\text { Maximum (mxT }_{\max }\right)\end{array}$} & \multicolumn{3}{|c|}{ 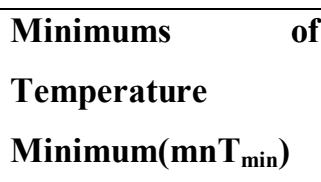 } \\
\hline & & & $\mathbf{R}^{2}$ & $\mathrm{CV}$ & & $\mathbf{R}^{2}$ & $\mathrm{CV}$ \\
\hline \multirow[t]{3}{*}{ Entebbe } & $1960-2009$ & 0.70 & 0.08 & $86 \%$ & -0.02 & 0.19 & $116 \%$ \\
\hline & $1960-1989$ & -0.02 & 0.23 & $37 \%$ & -0.06 & 0.40 & $113 \%$ \\
\hline & $1980-2009$ & 0.05 & 0.10 & $96 \%$ & 0.01 & 0.02 & $125 \%$ \\
\hline \multirow[t]{3}{*}{ Jinja } & $1960-2000$ & 0.003 & 0.05 & $73 \%$ & -0.02 & 0.04 & $70 \%$ \\
\hline & $1960-1989$ & -0.02 & 0.01 & $72 \%$ & -0.05 & 0.23 & $58 \%$ \\
\hline & $1971-2000$ & 0.03 & 0.02 & $73 \%$ & -0.03 & 0.03 & $81 \%$ \\
\hline \multirow{2}{*}{ Kabale } & $1960-2000$ & 0.01 & 0.04 & $61 \%$ & -0.01 & 0.02 & $42 \%$ \\
\hline & $1960-1989$ & 0.02 & 0.09 & $67 \%$ & -0.02 & 0.12 & $42 \%$ \\
\hline
\end{tabular}




\begin{tabular}{|l|l|l|l|l|l|l|l|}
\hline \multirow{4}{*}{ Masindi } & $1971-2000$ & 0.00 & 0.00 & 61 & 0.00 & 0.00 & $47 \%$ \\
\hline \multirow{5}{*}{ Mbarara } & $1965-2000$ & 0.01 & 0.00 & $50 \%$ & 0.00 & 0.00 & $57 \%$ \\
\cline { 2 - 8 } & $1965-1994$ & -0.02 & 0.01 & $50 \%$ & 0.01 & 0.01 & $58 \%$ \\
\cline { 2 - 8 } & $1971-2000$ & -0.00 & 0.00 & $49 \%$ & 0.00 & 0.01 & $57 \%$ \\
\hline \multirow{5}{*}{ Namulonge } & $1960-2008$ & 0.01 & 0.02 & $87 \%$ & -0.01 & 0.07 & $68 \%$ \\
\cline { 2 - 8 } & $1960-1989$ & -0.01 & 0.01 & $65 \%$ & -0.02 & 0.03 & $73 \%$ \\
\cline { 2 - 8 } & $1979-2008$ & 0.02 & 0.01 & $\mathbf{9 4} \%$ & 0.01 & 0.05 & $52 \%$ \\
\hline Soroti & $1953-2008$ & $\mathbf{- 0 . 0 3}$ & 0.08 & $69 \%$ & -0.01 & 0.00 & $\mathbf{1 3 4} \%$ \\
\cline { 2 - 8 } Tororo & $1953-1982$ & -0.02 & 0.01 & $71 \%$ & -0.03 & 0.04 & $58 \%$ \\
\cline { 2 - 8 } & $1979-2008$ & -0.04 & 0.1 & $58 \%$ & -0.12 & 0.07 & $\mathbf{1 6 5} \%$ \\
\hline \multirow{4}{*}{ Area average series } & $1971-2000$ & -0.03 & 0.05 & $32 \%$ & -0.00 & 0.00 & $\mathbf{1 2 1} \%$ \\
\cline { 2 - 8 } & $1961-1996$ & -0.00 & 0.00 & $46 \%$ & -0.00 & 0.00 & $55 \%$ \\
\cline { 2 - 8 } & $1961-1990$ & -0.01 & 0.00 & $46 \%$ & -0.02 & 0.09 & $58 \%$ \\
\cline { 2 - 8 } & $1965-1996$ & 0.02 & 0.001 & $43 \%$ & -0.01 & 0.01 & $58 \%$ \\
\cline { 2 - 8 } & $1971-2000$ & -0.05 & 0.10 & & -0.00 & 0.00 & \\
\hline
\end{tabular}

Generally, the mean trend in intra-annual variance is decreasing, but the downward trend is not statistically significant (figures $2 \mathrm{a}-2 \mathrm{~h}$ ). The coefficients of variance calculations reveal that maximum temperatures of the area average series are more varied compared to the minimum temperature at these stations of Uganda (table 3).
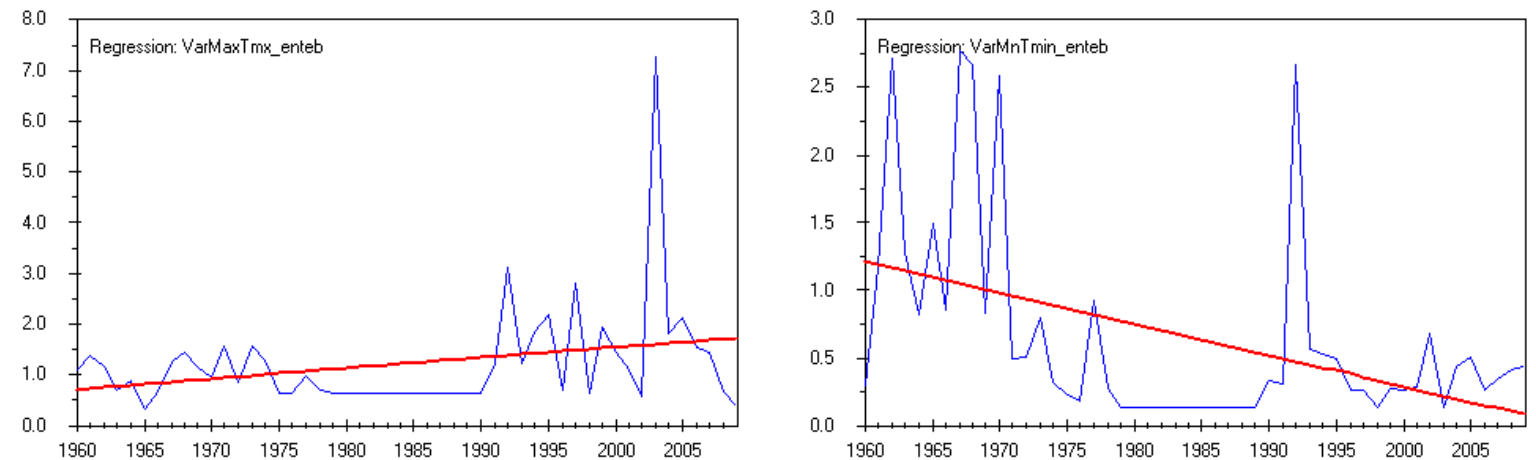

a) 

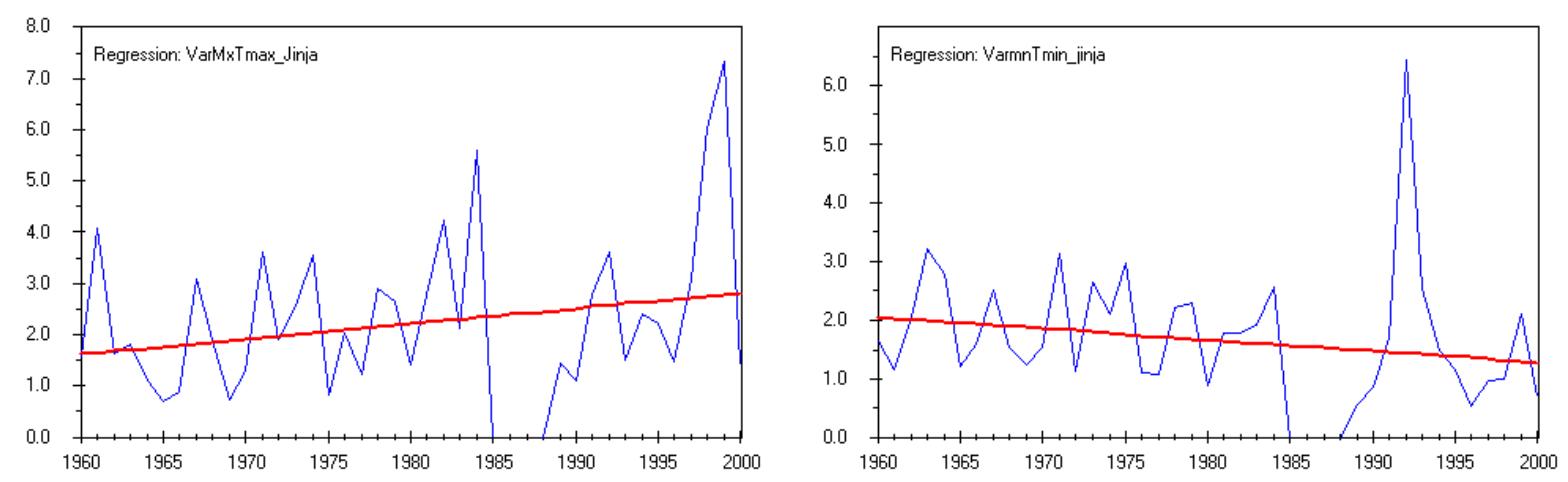

b)
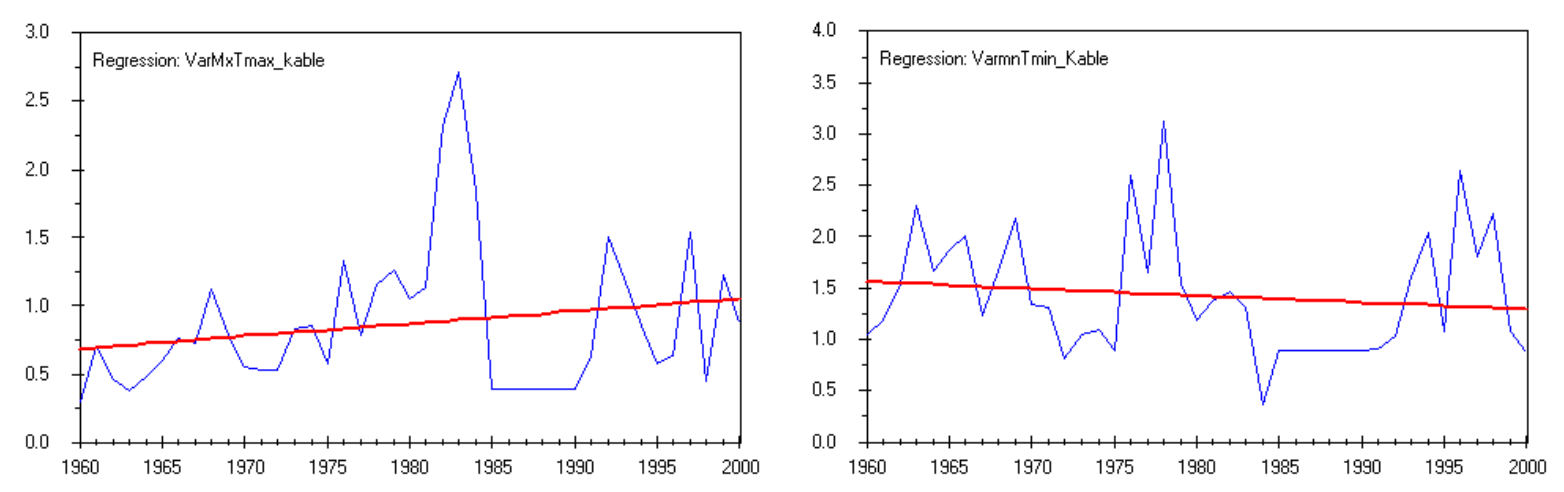

c)
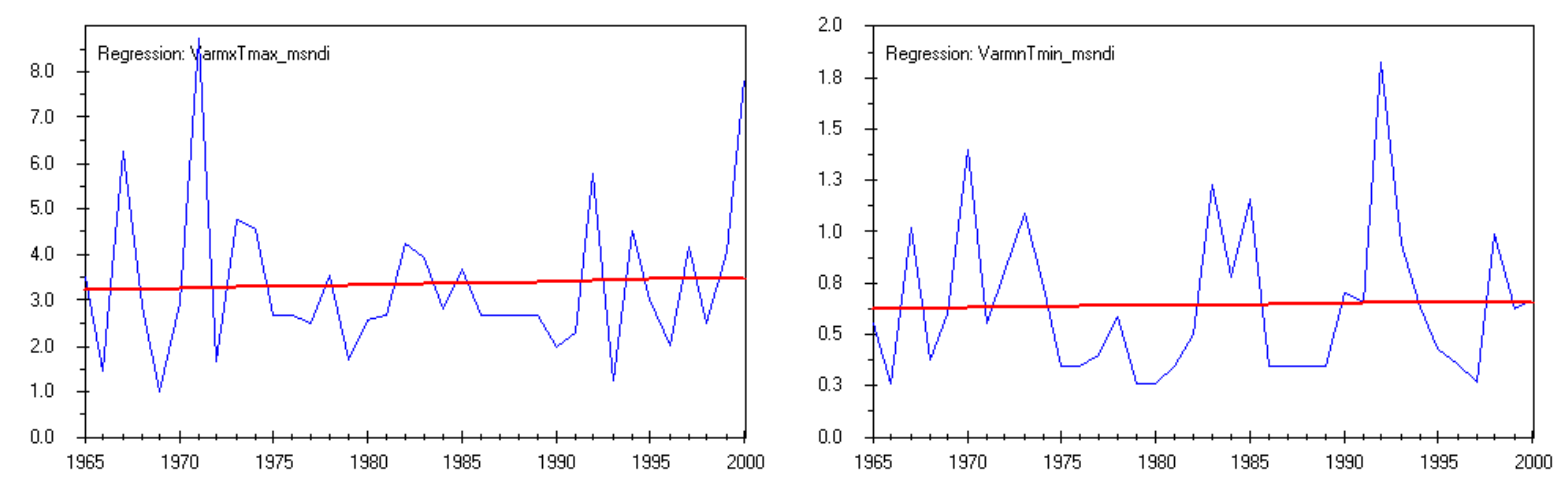

d) 

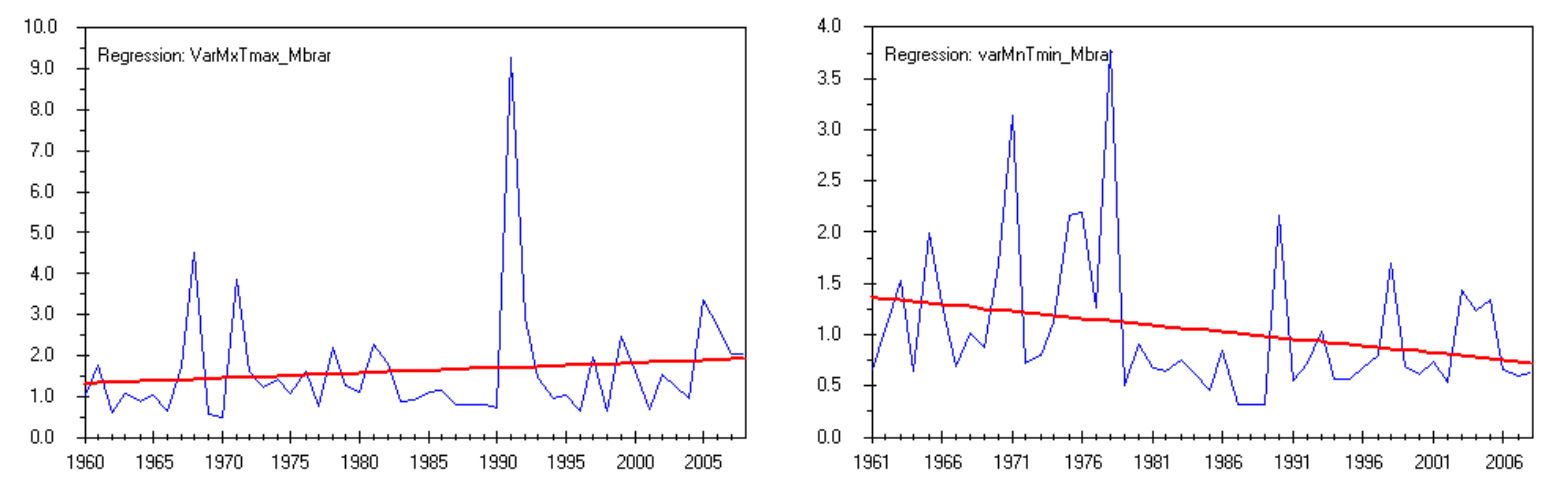

e)
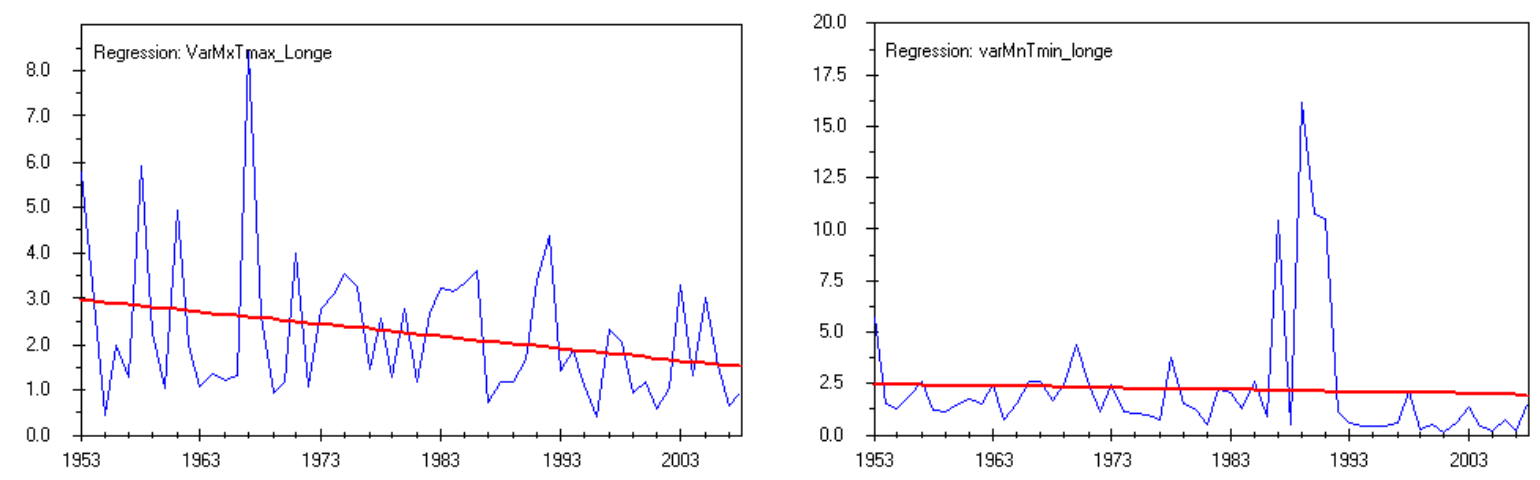

f)
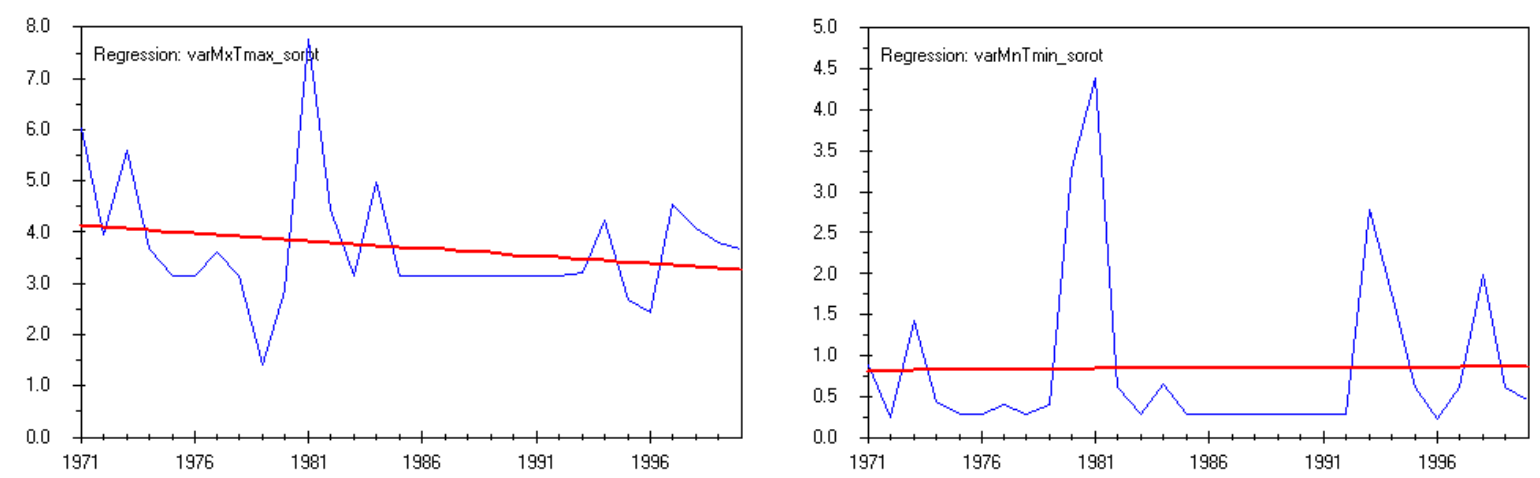

g) 

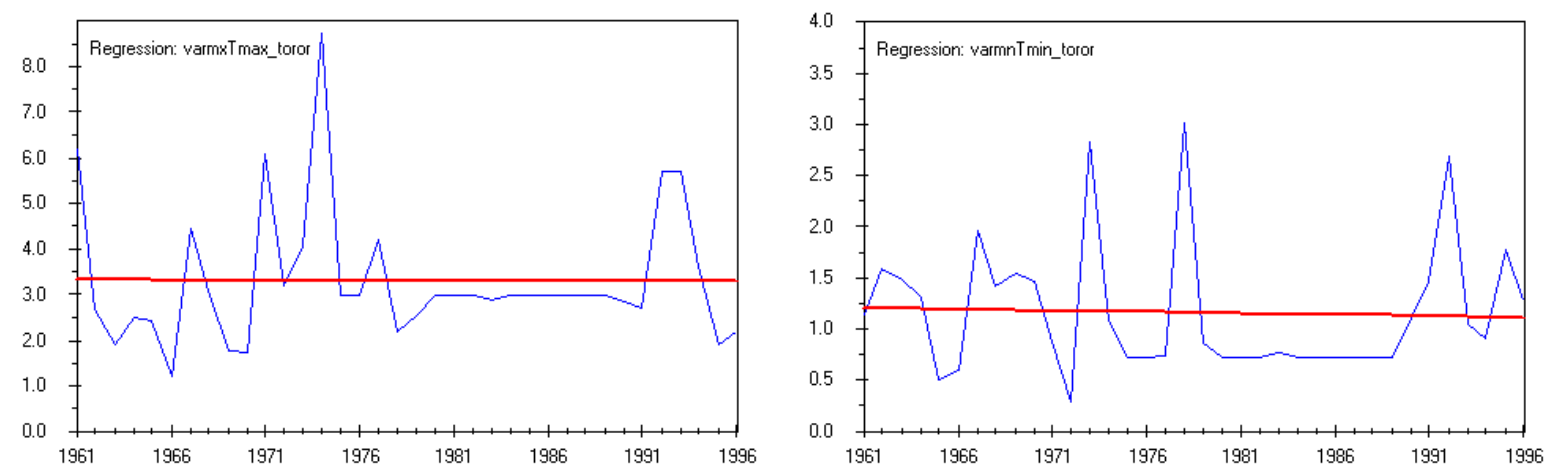

h)

Fig. 2(a -h) above show plots for trends in variance for stations in Uganda namely, (a) Entebbe, (b) Jinja, (c) Kabale, (d) Masindi, (e) Mbarara, (f) Namulonge, (g) Soroti, (h) Tororo. Figures on the left represent mx $\mathrm{T}_{\max }$, and those on the right represent $\mathrm{mnT}_{\text {min }}$

\subsection{Trends in extreme temperature and temperature events.}

\subsubsection{Hot extremes (Hot days, Warm nights, Hottest day, Hot night, Coolest day and Warm spells).}

The study reveals that, hottest days have increased significantly in the period of analysis at all stations. This positive trend in hottest days signifies that, Uganda is experiencing increased incidents in the extremes of the maximum temperature. This positive trend is strong for Mbarara, Masindi and Kabale (Table 4). Furthermore results show that hot days $\left(>25^{\circ} \mathrm{C}\right)$ have increased significantly at all the stations. The magnitude of change is very strong for Mbarara, Namulonge and Tororo stations. The increase in hot days however for Entebbe and Soroti is not statistically significant. Similarly the coolest day analysis at all the stations, depicts a positive trend. The trend is statistically significant at $p<0.01$ for six of the stations, but very strong for Tororo and Masindi (Table 4). The increase experienced in Jinja and Entebbe however, is not statistically significant.

Furthermore, the study has revealed a strong significant positive trend for warm nights in Entebbe and Masindi, while the trend at Namulonge is negative and statistically not significant (Table 4). Hot nights have increased over the analysis period at all stations except for Namulonge where the decrease is not significant (Table 4). The frequency of hot days is also high at Soroti (38.9\%), Tororo (34.5\%) and Kabale (33.1\%) and lowest at Mbarara (20.4\%). The 
frequency of hot nights is high in Masindi (32.9\%) and Soroti (33.3\%), while Mbarara shows the lowest of hot night frequencies.

Table 4. Trends in hot extreme indices of temperature and Mann- Kendall test for trend ( $z$-statistics) at reference stations in Uganda. Bold values indicate trends statistically significant at $p<0.01$ and $p<0.05$.

\begin{tabular}{|c|c|c|c|c|c|c|c|c|c|}
\hline Indices & Unit & Entebbe & Jinja & Kabale & Masindi & Mbarara & Namulonge & Soroti & Tororo \\
\hline Hot days & Days & $0.94^{\mathrm{d}}$ & $1.91^{\mathrm{c}}$ & $2.41^{b}$ & $2.30^{b}$ & $3.69^{\mathrm{a}}$ & $3.94^{\mathrm{a}}$ & $0.38^{\mathrm{d}}$ & $3.51^{\mathrm{a}}$ \\
\hline $\begin{array}{l}\text { Warm } \\
\text { nights }\end{array}$ & Days & $2.97^{a}$ & $1.79^{\mathrm{c}}$ & 0 trend & $2.87^{a}$ & 0 trend & $-0.81^{d}$ & $0.64^{\mathrm{d}}$ & $1.64^{d}$ \\
\hline $\begin{array}{l}\text { Hottest } \\
\text { day }\end{array}$ & ${ }^{0} \mathrm{C}$ & $2.94^{\mathrm{a}}$ & $2.46^{b}$ & $4.42^{a}$ & $5.68^{a}$ & $6.51^{\mathrm{a}}$ & $2.53^{b}$ & $3.23^{a}$ & $3.66^{\mathrm{a}}$ \\
\hline $\begin{array}{l}\text { Hot day } \\
\text { frequency }\end{array}$ & $\%$ & 26.6 & 25 & 33.1 & 28.2 & 20.4 & 24.0 & 38.9 & 34.5 \\
\hline $\begin{array}{l}\text { Hot night } \\
\text { frequency }\end{array}$ & $\%$ & 21.5 & 21.95 & 20.7 & 32.9 & 13.4 & 16.4 & 33.3 & 15.5 \\
\hline $\begin{array}{l}\text { Coolest } \\
\text { day }\end{array}$ & ${ }^{0} \mathrm{C}$ & $0.72^{\mathrm{d}}$ & $1.46^{\mathrm{d}}$ & $2.31^{a}$ & $3.66^{a}$ & $2.97^{a}$ & $2.98^{a}$ & $2.80^{a}$ & $4.05^{a}$ \\
\hline Period & Years & $\begin{array}{l}1960- \\
2009\end{array}$ & $\begin{array}{l}1960- \\
2000\end{array}$ & $\begin{array}{l}1960- \\
2000\end{array}$ & $\begin{array}{l}1965- \\
2000\end{array}$ & $\begin{array}{l}1960- \\
2008\end{array}$ & 1953-2008 & $\begin{array}{l}1971- \\
2000\end{array}$ & $\begin{array}{l}1961- \\
1996\end{array}$ \\
\hline
\end{tabular}

${ }^{a}$ Trends statistically significant at $p<0.01 ;{ }^{\mathrm{b}}$ Trends statistically significant at $p<0.05$

${ }^{\mathrm{c}}$ Trends statistically significant at $p<0.10 ;{ }^{\mathrm{d}}$ No significant trend

Detailed analysis of maximum temperatures shows that, warm spells have increased during the period of study. Warm spells often occur during the first quarter of every year and their trend is increasing (figures 3a-3h). The graphs indicate that, high counts of warm spells have been more apparent after the 1980s at all stations. 


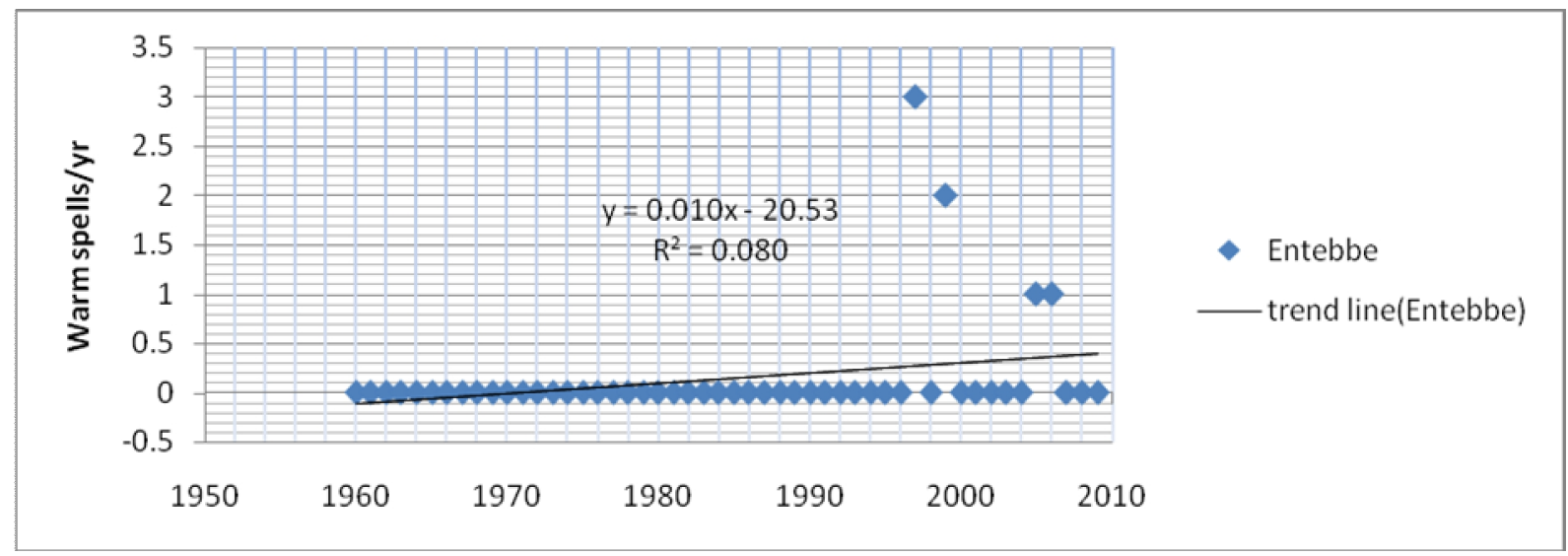

a)

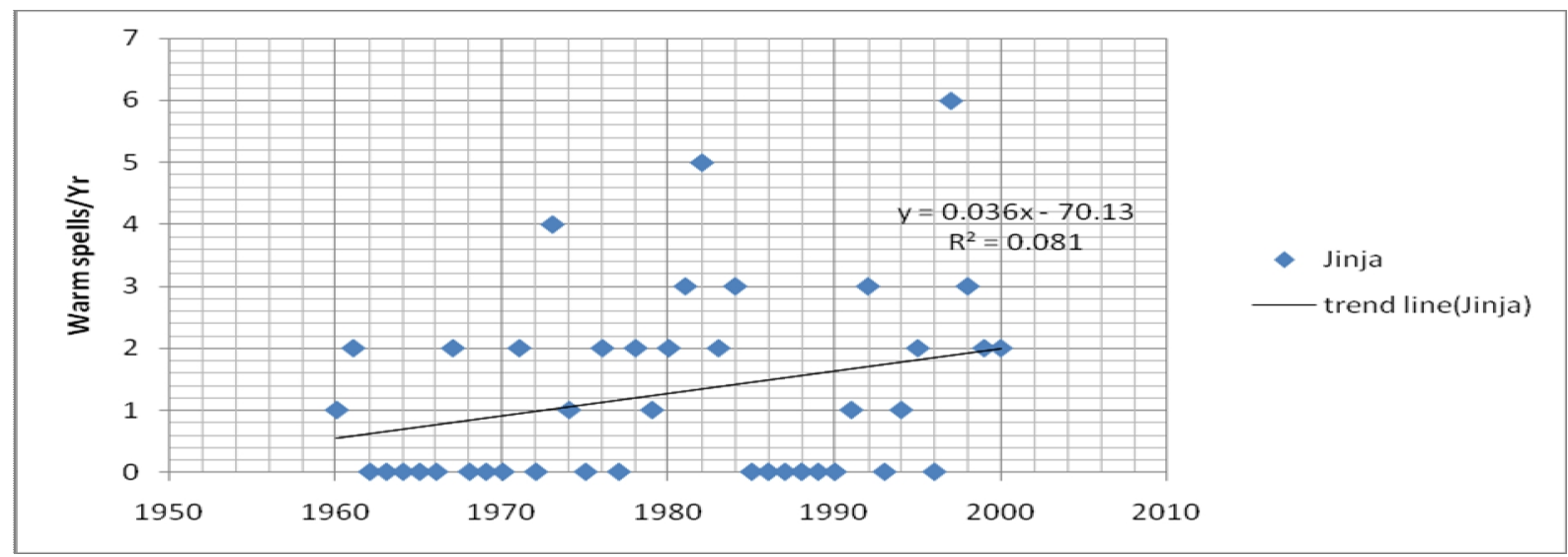

b)

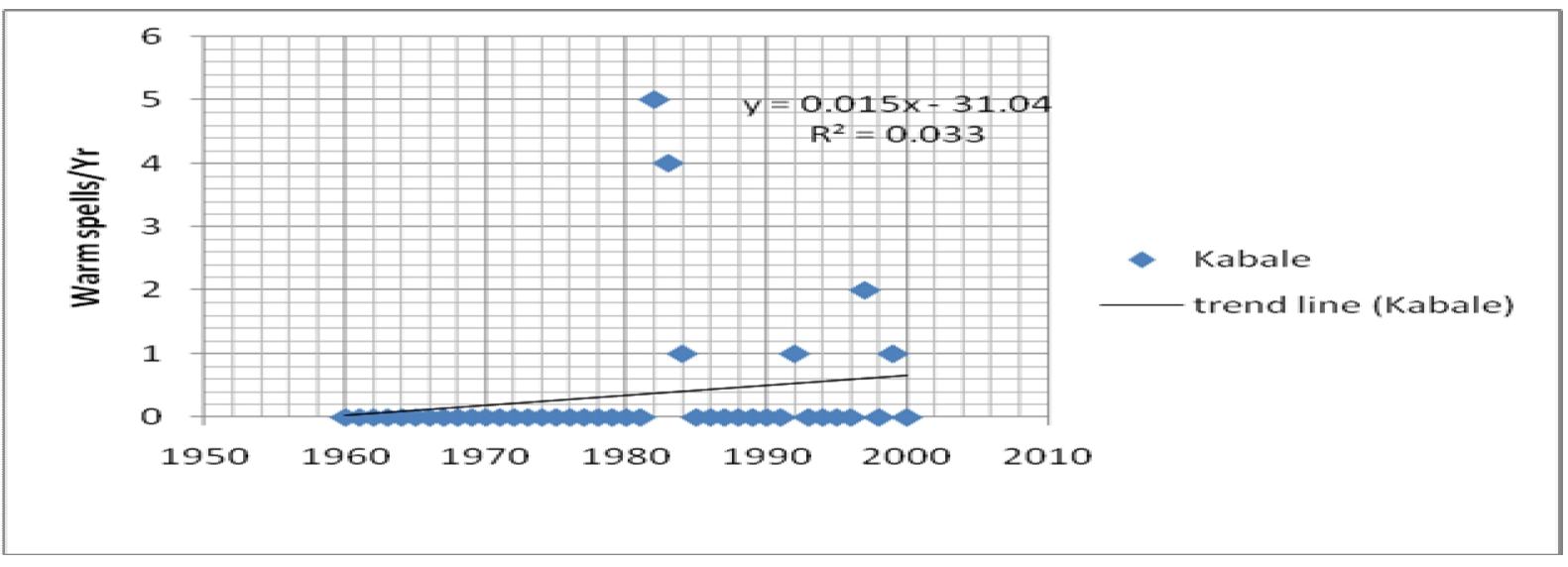

c) 


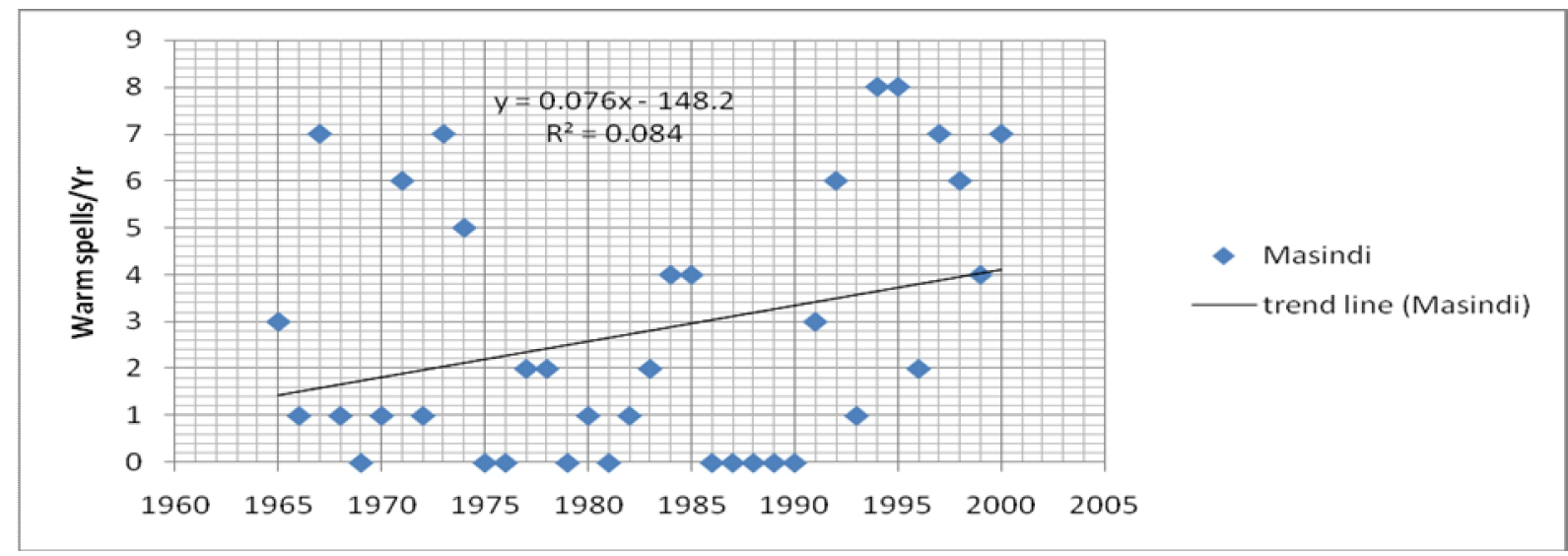

d)

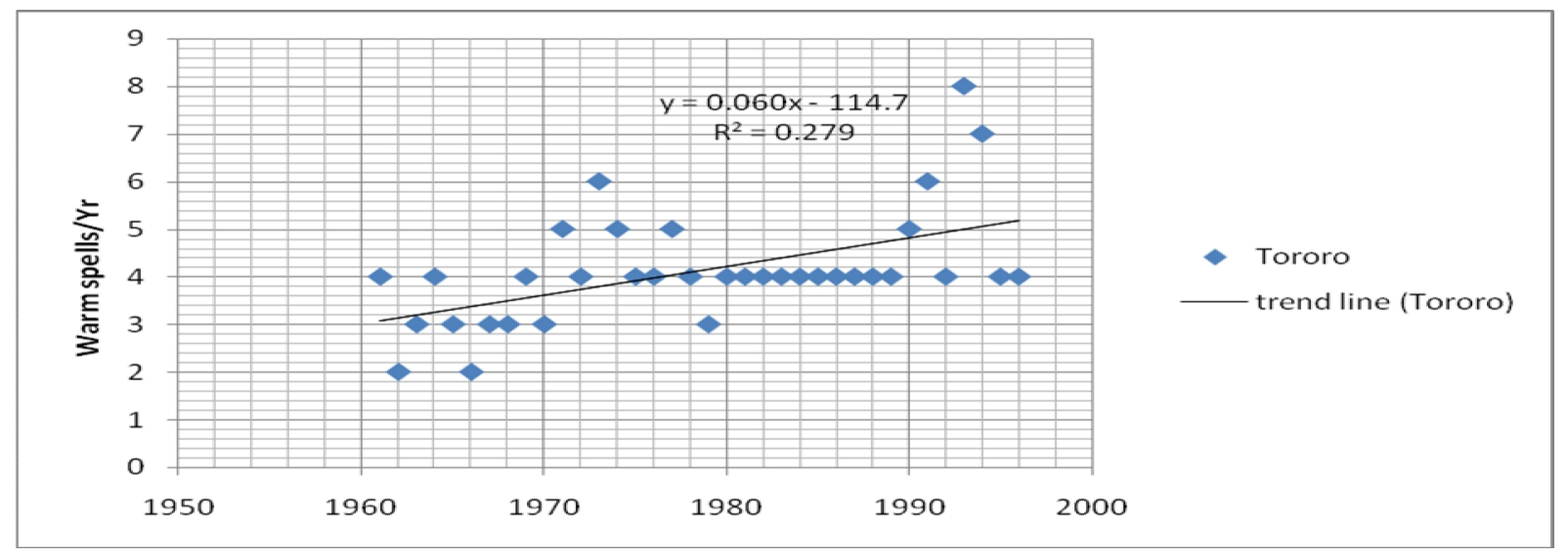

e)

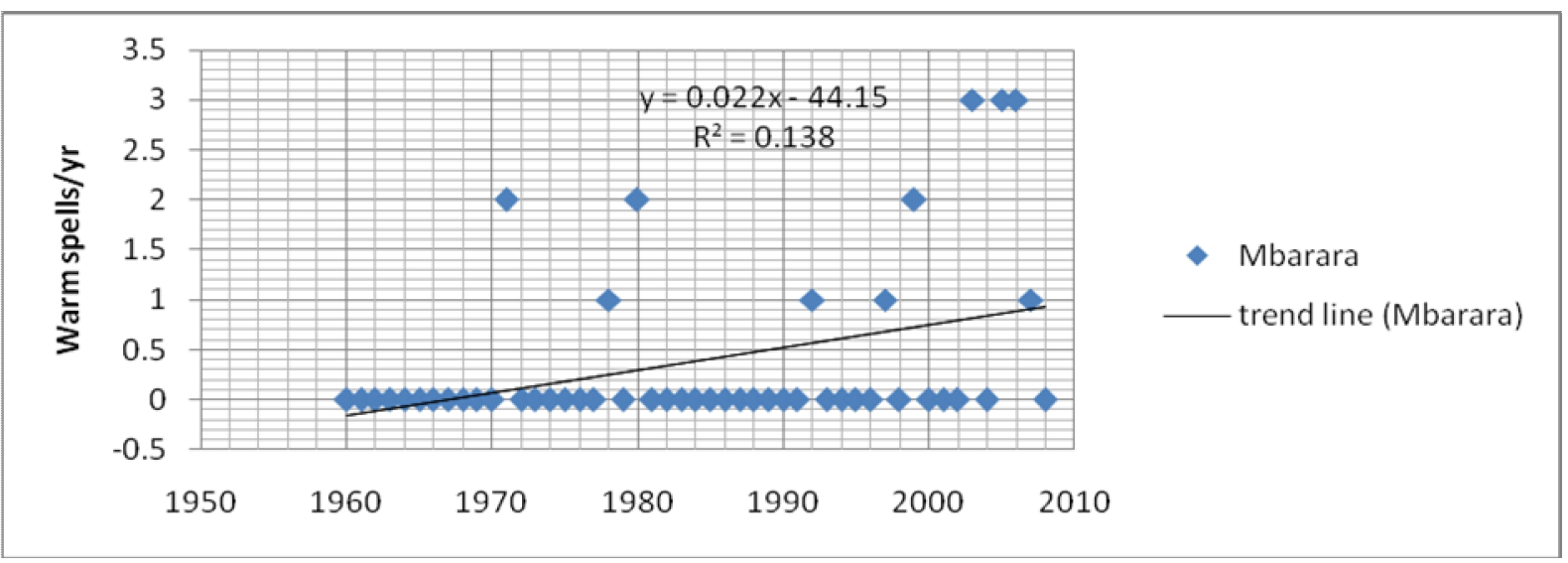

f) 


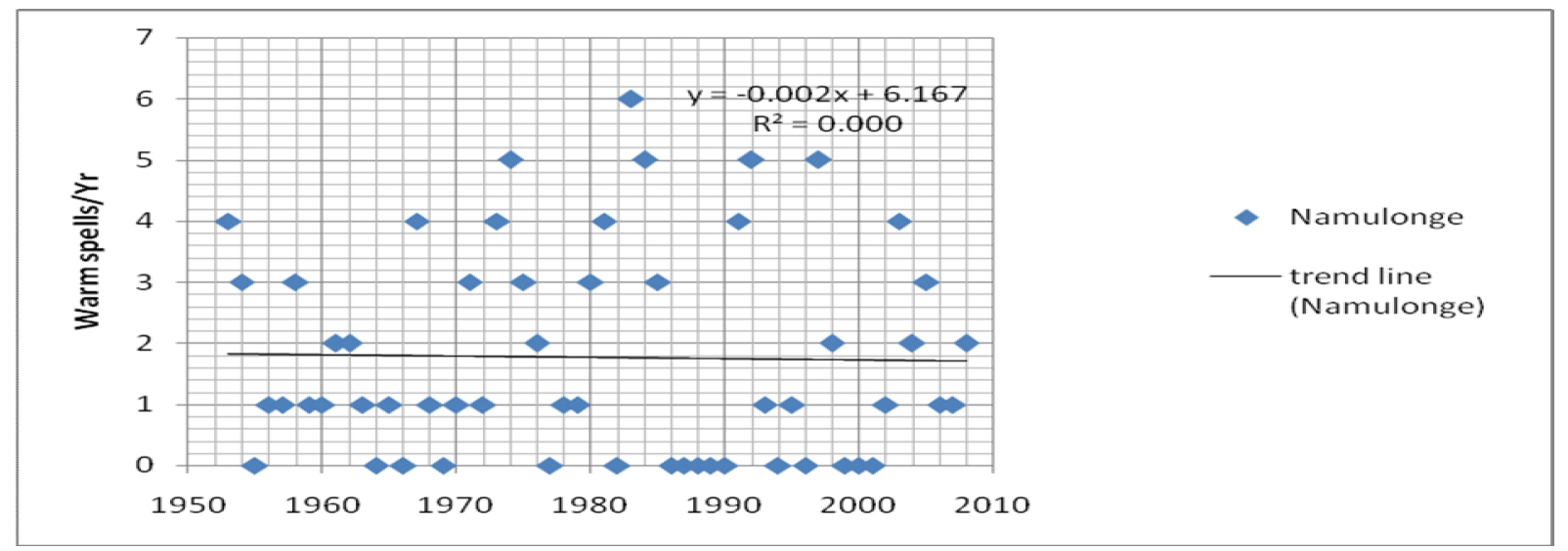

g)

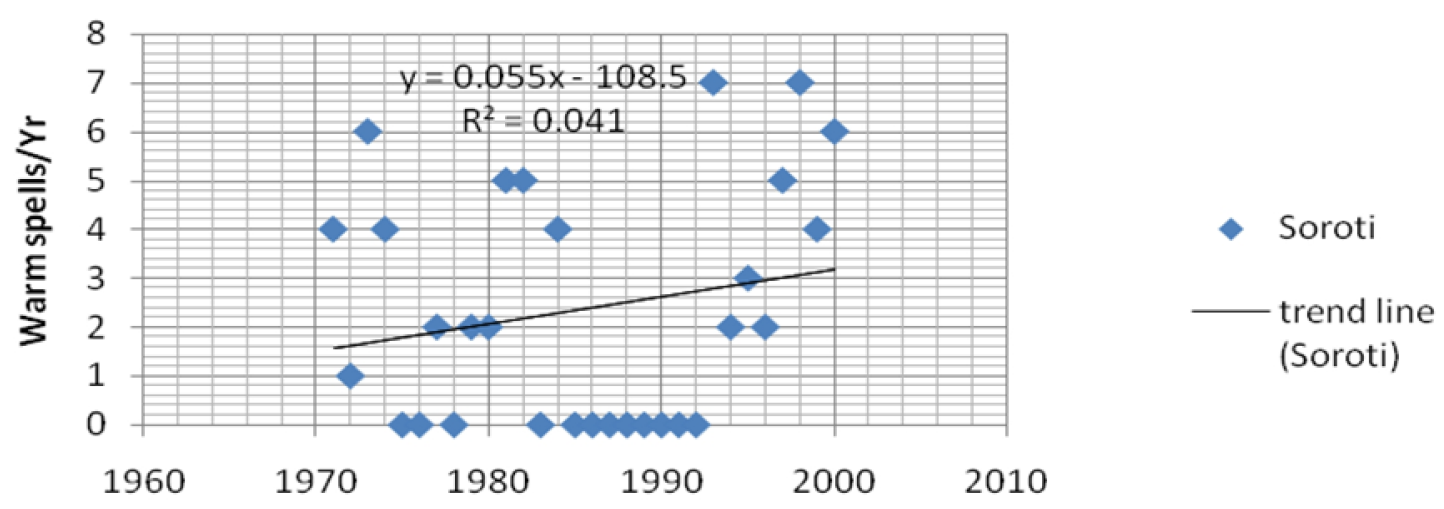

h)

Fig. 3 (a-h) show distributions of warm spells at different stations used for the study.

\subsubsection{Cold extremes (cool night, cool day, hottest night and coolest night).}

The frequency of cool days is high at Soroti (38.9\%), Entebbe (36.5\%) and Tororo (30.1\%), and lowest at Namulonge and Kabale $(23 \%)$. Analysis also reveals a positive trend $(p<0.01)$ for the coolest nights for all the stations except at Soroti, which reflected a no significant trend (table 5). The magnitude of trend is strong for Mbarara, Entebbe, Masindi and Kabale. Cool night frequency is very high in Kabale (30.3\%) and lowest in Soroti $(10.3 \%)$, which could be partly due to altitude (table 1). Hottest night temperatures for Entebbe, Kabale, Masindi, Mbarara, and Tororo show very strong positive trends at $p<0.01$ (table 5). 
Table 5. Trends in cold extreme indices of temperature and Mann- Kendall test for trend ( $\mathrm{Z}$-statistics) at reference stations in Uganda. Bold values indicate trends statistically significant at $p<0.01$ and $p<0.05$.

\begin{tabular}{|c|c|c|c|c|c|c|c|c|c|}
\hline Indices & Unit & Entebbe & Jinja & Kabale & Masindi & Mbarara & Namulonge & Soroti & Tororo \\
\hline $\begin{array}{l}\text { Coolest } \\
\text { night }\end{array}$ & ${ }^{0} \mathrm{C}$ & $6.31^{\mathrm{a}}$ & $3.24^{\mathrm{a}}$ & $5.38^{a}$ & $5.54^{\mathrm{a}}$ & $6.77^{\mathrm{a}}$ & $2.99^{a}$ & $0.55^{\mathrm{d}}$ & $3.96^{\mathrm{a}}$ \\
\hline $\begin{array}{l}\text { Cool } \\
\text { night } \\
\text { frequency }\end{array}$ & $\%$ & 12.5 & 19.3 & 30.3 & 17.8 & 13.5 & 21.9 & 10.3 & 23.4 \\
\hline $\begin{array}{l}\text { Cool day } \\
\text { frequency }\end{array}$ & $\%$ & 36.5 & 28.9 & 23.4 & 27.5 & 27.0 & 23.2 & 38.9 & 30.1 \\
\hline $\begin{array}{l}\text { Hottest } \\
\text { night }\end{array}$ & ${ }^{0} \mathrm{C}$ & $5.19^{a}$ & $1.45^{\mathrm{c}}$ & $4.17^{a}$ & $5.75^{a}$ & $6.54^{\mathrm{a}}$ & $-1.29^{d}$ & $1.39^{\mathrm{d}}$ & $4.73^{a}$ \\
\hline Period & Years & $\begin{array}{l}1960- \\
2009\end{array}$ & $\begin{array}{l}1960- \\
2000\end{array}$ & $\begin{array}{l}1960- \\
2000\end{array}$ & $\begin{array}{l}1965- \\
2000\end{array}$ & $\begin{array}{l}1960- \\
2008\end{array}$ & 1953-2008 & $\begin{array}{l}1971- \\
2000\end{array}$ & $\begin{array}{l}1961- \\
1996\end{array}$ \\
\hline
\end{tabular}

${ }^{a}$ Trends statistically significant at $p<0.01 ;{ }^{\mathrm{b}}$ Trends statistically significant at $p<0.05$

${ }^{\mathrm{c}}$ Trends statistically significant at $p<0.10 ;{ }^{\mathrm{d}}$ No significant trend

\subsubsection{Mean annual Diurnal temperature range (DTR)}

Results show that, mean annual DTR trend at six (Entebbe, Jinja, Kabale, Masindi, Mbarara and Tororo) of the stations is negative, but the magnitude for Entebbe and Mbarara is very strong. On the other hand, positive trends are experienced at Namulonge and Soroti at $\mathrm{p}<0.01$ (table 6). This finding concurs with Kruger and Shongwe (2004) that, the general global trend for diurnal temperature range has been negative. This decline in DTR resulting from decrease in minimums shows that, temperatures have warmed, which result is not very different from what Nicolls et al., 1996 in (Hulme et al. 2001) has found to have happened to most of the global surface temperatures. 
Table 6. Trends in diurnal range of temperature and Mann- Kendall test for trend ( $Z$-statistics) at reference stations in Uganda. Bold values indicate trends statistically significant at $p<0.01$ and $p<0.05$.

\begin{tabular}{|l|l|l|l|l|l|l|l|l|l|}
\hline Indices & Unit & Entebbe & Jinja & Kabale & Masindi & Mbarara & Namulonge & Soroti & Tororo \\
\hline DTR & ${ }^{0} \mathrm{C}$ & $\mathbf{- 6 . 3 9}^{\mathbf{a}}$ & $-0.67^{\mathrm{d}}$ & $-1.32^{\mathrm{d}}$ & $-1.21^{\mathrm{d}}$ & $\mathbf{- 4 . 0 5}^{\mathbf{a}}$ & $\mathbf{3 . 0 9}^{\mathbf{a}}$ & $\mathbf{3 . 7 6}^{\mathbf{a}}$ & $-0.84^{\mathrm{d}}$ \\
\hline Period & Years & $1960-$ & $1960-$ & $1960-$ & $1965-$ & $1960-$ & $1953-2008$ & $1971-$ & $1961-$ \\
& & 2009 & 2000 & 2000 & 2000 & 2008 & & 2000 & 1996 \\
\hline
\end{tabular}

${ }^{\mathrm{a}}$ Trends statistically significant at $p<0.01 ;{ }^{\mathrm{b}}$ Trends statistically significant at $p<0.05$

${ }^{\mathrm{c}}$ Trends statistically significant at $p<0.10 ;{ }^{\mathrm{d}}$ No significant trend

\subsubsection{Annual temperature range (ATR)}

The study also reveals that the trend for annual temperature range $\left(m x T_{\max }-m n T_{\min }\right)$ for seven of the stations is negative (table 7). This decreasing trend is strong for Entebbe and Mbarara while stations of Jinja, Kabale, Masindi, Namulonge and Tororo have trends, which are not statistically significant. This implies that the gap between maximum and minimum extremes is reducing which supports the fact that minimums are warming at the studied stations.

Table 7. Trends in annual range of temperature and Mann- Kendall test for trend ( $Z$-statistics) at reference stations in Uganda. Bold values indicate trends statistically significant at $p<0.01$ and $p<0.05$.

\begin{tabular}{|l|l|l|l|l|l|l|l|l|l|}
\hline Indices & Unit & Entebbe & Jinja & Kabale & Masindi & Mbarara & Namulonge & Soroti & Tororo \\
\hline ATR & ${ }^{0} \mathrm{C}$ & $\mathbf{- 4 . 9 4}^{\mathbf{a}}$ & $-0.49^{\mathrm{d}}$ & $-1.57^{\mathrm{d}}$ & $-0.69^{\mathrm{d}}$ & $\mathbf{- 3 . 6 4 ^ { \mathbf { b } }}$ & $-0.07^{\mathrm{d}}$ & $2.05^{\mathrm{c}}$ & $-0.94^{\mathrm{d}}$ \\
\hline Period & Years & $1960-$ & $1960-$ & $1960-$ & $1965-$ & $1960-$ & $1953-2008$ & $1971-$ & $1961-$ \\
& & 2009 & 2000 & 2000 & 2000 & 2008 & & 2000 & 1996 \\
\hline
\end{tabular}

${ }^{\mathrm{a}}$ Trends statistically significant at $p<0.01 ;{ }^{\mathrm{b}}$ Trends statistically significant at $p<0.05$

${ }^{\mathrm{c}}$ Trends statistically significant at $p<0.10$; ${ }^{\mathrm{d}}$ No significant trend

\subsection{Trends in mean monthly maximum, minimum and mean annual temperature.}

\subsubsection{Area averaged trend}

There are 8 available meteorological stations with over 35 years of temperature record for this study. These records have been aggregated into area average annual series following the method in the section 2.9 above. Correlation Coefficients tests show that, station series correlate between 
0.1 and 0.9 (Figure 4). Series whose correlation was below 0.4 were omitted while generating the area average series for a particular variable.

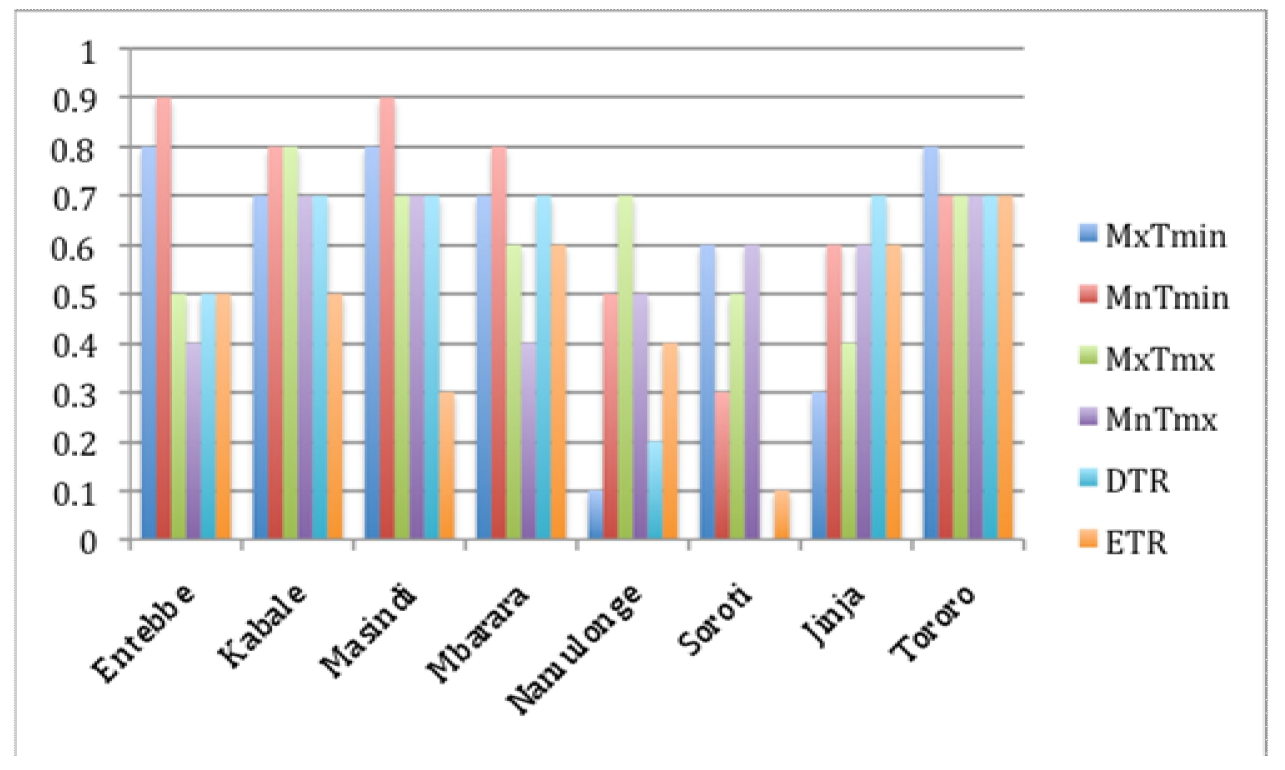

Figure 4 Frequency distribution of correlation coefficients between rainfall at individual stations and the corresponding regional average annual series.

Overall, this criterion results in 6 stations for $\mathrm{mxT}_{\min }$ series, having omitted Namulonge and Jinja; 7 stations for $\mathrm{mnT}_{\min }$ series, excluding Soroti; 8 stations for $\mathrm{mxT}_{\max }$ and $\mathrm{mnT}_{\max }$ series, 6 stations for DTR, without Namulonge and Soroti and ATR not including Masindi and Soroti series.

The analysis indicates that the area average climate series derived for the region has experienced positive trends of $\mathrm{mnT}_{\max }, \mathrm{mnT}_{\min }, \mathrm{mxT}_{\max }, \mathrm{mnT}_{\max }$ temperature series for the last 41 years. The $\mathrm{Z}$ values for the MK statistic reveals that annual series have experienced very strong significant trends in the past decades. There is an indication that both daytime and nighttime hot extremes are increasing. Such a finding is not far from what New et al., (2006) have found in their study. Evidence against null hypothesis $\left(\mathrm{H}_{\mathrm{o}}\right)$ for $\mathrm{mnT}_{\max } \mathrm{mnT}_{\min }, \mathrm{mxT}_{\max }$ and $\mathrm{mnT}_{\max }$ for every month is strong and statistically significant $(\mathrm{a}<0.05$ and $\mathrm{a}<0.1)$. On the other hand the increasing trend with in the minimums $\left(\mathrm{mnT}_{\min }\right.$ and $\left.\mathrm{mxT}_{\min }\right)$ shows very strong evidence against $\mathrm{H}_{\mathrm{o}}$.

Majority of the months are statistically significant $a<0.01$ (table 8 ). The changes are statistically significant except for a few months of the maximum temperatures indicated in bold. It can be concluded for this region that the nights are warming faster compared to the day. This research is 
not able to explain the cause of such warming, which could be a result of higher humidity levels that can contract the daily temperature range among other factors.

Table 8. Trends in monthly maximum, minimum and annual temperature and Mann- Kendall test for trend ( $z$ statistics) of the area average climate series in Uganda.

\begin{tabular}{|c|c|c|c|c|c|c|c|c|c|c|c|c|c|c|}
\hline Indices & Tests & Jan & Feb & Mar & Apr & May & Jun & Jul & Aug & Sep & Oct & Nov & Dec & Annual \\
\hline \multirow{3}{*}{$\begin{array}{l}\text { Minimum } \\
\text { Temp } \\
\text { Maximum }\end{array}$} & $\begin{array}{l}\text { L.Reg } \\
\text { test }(\sigma)\end{array}$ & 0.01 & 0.01 & 0.01 & 0.01 & 0.01 & 0.02 & 0.02 & 0.01 & 0.01 & 0.01 & 0.01 & 0.01 & 0.01 \\
\hline & $\begin{array}{l}\text { MK } \\
\text { test(z) }\end{array}$ & 0.67 & 1.76 & 1.75 & 0.88 & 0.12 & 1.03 & 1.62 & 2.01 & 1.63 & 0.57 & 2.39 & 2.85 & 3.17 \\
\hline & $\begin{array}{l}\text { Signif. } \\
\text { (At a.. }\end{array}$ & $=0.10$ & $<0.1$ & $<0.1$ & $=0.10$ & $=0.10$ & $=0.10$ & $=0.10$ & $<0.05$ & $=0.10$ & $=0.10$ & $<0.05$ & $<0.01$ & $<0.01$ \\
\hline \multirow{3}{*}{$\begin{array}{l}\text { Minimum } \\
\text { Temp } \\
\text { Minimum }\end{array}$} & $\begin{array}{l}\text { L.Reg } \\
\text { test }(\sigma)\end{array}$ & 0.01 & 0.01 & 0.01 & 0.01 & 0.01 & 0.01 & 0.01 & 0.01 & 0.01 & 0.01 & 0.01 & 0.01 & 0.01 \\
\hline & $\begin{array}{l}\text { MK } \\
\text { test(z) }\end{array}$ & 3.44 & 3.50 & 3.77 & 1.72 & 3.50 & 6.25 & 5.57 & 4.84 & 4.67 & 4.3 & 3.68 & 4.82 & 5.93 \\
\hline & $\begin{array}{l}\text { Signif. } \\
\text { (At a.. }\end{array}$ & $<0.01$ & $<0.01$ & $<0.01$ & $<0.1$ & $<0.01$ & $<0.01$ & $<0.01$ & $<0.01$ & $<0.01$ & $<0.01$ & $<0.01$ & $<0.01$ & $<0.01$ \\
\hline \multirow{3}{*}{$\begin{array}{l}\text { Maximum } \\
\text { Temp } \\
\text { Maximum }\end{array}$} & $\begin{array}{l}\text { L.Reg } \\
\text { test }(\sigma)\end{array}$ & 0.01 & 0.01 & 0.01 & 0.01 & 0.01 & 0.01 & 0.01 & 0.01 & 0.01 & 0.01 & 0.01 & 0.01 & 0.01 \\
\hline & $\begin{array}{l}\text { MK } \\
\text { test( }(z)\end{array}$ & 2.04 & 2.57 & 2.01 & 1.85 & 3.19 & 2.67 & 3.79 & 2.72 & 3.1 & 1.92 & 1.15 & 1.42 & 4.50 \\
\hline & $\begin{array}{l}\text { Signif. } \\
\text { (At a.. }\end{array}$ & $<0.05$ & $<0.05$ & $<0.05$ & $<0.1$ & $<0.01$ & $<0.05$ & $<0.01$ & $<0.01$ & $<0.01$ & $<0.1$ & $=0.10$ & $=0.10$ & $<0.01$ \\
\hline \multirow{3}{*}{$\begin{array}{l}\text { Maximum } \\
\text { Temp } \\
\text { Minimum }\end{array}$} & $\begin{array}{l}\text { L.Reg } \\
\text { test }(\sigma)\end{array}$ & 0.01 & 0.01 & 0.01 & 0.01 & 0.01 & 0.01 & 0.01 & 0.01 & 0.01 & 0.01 & 0.01 & 0.01 & 0.01 \\
\hline & $\begin{array}{l}\text { MK } \\
\text { test(z) }\end{array}$ & 3.75 & 2.62 & 2.78 & 2.50 & 1.98 & 3.75 & 4.1 & 4.28 & 4.19 & 4.01 & 3.77 & 3.54 & 5.01 \\
\hline & $\begin{array}{l}\text { Signif. } \\
\text { (At a.. }\end{array}$ & $<0.01$ & $<0.01$ & $<0.01$ & $<0.05$ & $<0.05$ & $<0.01$ & $<0.01$ & $<0.01$ & $<0.01$ & $<0.01$ & $<0.01$ & $<0.01$ & $<0.01$ \\
\hline
\end{tabular}


Table 9. Test for trends on ETR and DTR indices of the regional series

\begin{tabular}{|c|c|c|c|}
\hline Indices & Unit & Mann-Kendall test & Linear trend test \\
\hline \multirow[t]{3}{*}{ ATR } & \multirow[t]{3}{*}{${ }^{0} \mathrm{C}$} & (S) -231 & Sigma: 0.02 \\
\hline & & $(\mathbf{Z})-2.58$ & t-statistic: -3.04 \\
\hline & & $\begin{array}{l}\text { Statistically. Significant } \\
\text { trend at }(a<0.01)\end{array}$ & $\begin{array}{l}\text { Statistically. } \\
\text { Significant trend at } \\
(a<0.01)\end{array}$ \\
\hline \multirow[t]{3}{*}{ DTR } & \multirow[t]{3}{*}{${ }^{0} \mathrm{C}$} & (S) -138 & Sigma: 0.02 \\
\hline & & $(\mathbf{Z})-1.87$ & t-statistic: -3.19 \\
\hline & & $\begin{array}{l}\text { Statistically. Significant } \\
\text { trend at }(a<0.1)\end{array}$ & $\begin{array}{l}\text { Statistically. } \\
\text { Significant } \\
\text { at }(a<0.01)\end{array}$ \\
\hline
\end{tabular}

Table 9. Test for trends on ATR and DTR indices of the area average series

Tests indicate that ATR and DTR series have statistically significant decreasing linear trends $(\mathrm{a}<$ 0.01 ) at a rate of $0.1 \%$ per annum. New et al., (2006) also found a decrease in DTR trends for countries north of their study region, among which is Uganda.

Bodri and Cermak,(2003) observe that climate systems are variable on all time scales, and are better understood when one focuses on changes in climate variability and climate extremes. Simulations of climate predict not only climate warming but also a general decrease in climate variability. Our findings reveal an observed mean trend towards warmer temperature in Uganda, characterized by an increase in the minimum daily temperature. Maximum daily temperatures have increased at a much smaller rate, resulting in a decreasing trend in the diurnal temperature range. This is consistent with the mean global trend, which has projected a decrease in DTR (Stone and Weaver, 2003). The increase in hot nights at most of the stations investigated, will impact on people who have to spend more on cooling facilities. In situations where one cannot afford to purchase a fan, then they will be forced to keep windows open at night to allow cool air into the house. Such a practice will have consequences in that household members will be exposed to mosquito bites and thus may catch malaria. 
The warming trend is likely to exacerbate the constraints on life and livelihood activities, water resources for human consumption and watering of livestock as well as affecting crop water balances. Domestic livestock like other animals have a climate envelope in which they perform optimally. Increase in temperatures will lead to decline in milk and meat production, largely because animals remain in shades instead of foraging (Boko et al., 2007). In the tropics and subtropics in which Uganda is located, most of the crops are generally assumed to already have reached their highest temperature tolerance levels, and studies indicate that crop yields would be reduced as a result of increases in temperature, hence affecting food security. Additional evidence points to pest incidences (e.g Coffee Berry borer, Jaramillo, 2009) increasing in response to a rise in temperatures and this might result in reductions in crop production (IPCC, 2007). The response of increased temperatures on water demand and feed resources of livestock is something that should be considered (Thornton et al., 2007).

\section{Conclusions}

This study is a first attempt to characterize temperature trends and its variability in Uganda in recent decades. We have unveiled the trends of temperature at selected stations from the central and southern parts of the Uganda. Data was tested for normality as required to test for linear regression trend analysis, data showed normal distribution. The series were also tested for homogeneity, in which we established that there were not homogeneous, but this inhomogeneity could not be explained because of the absence of historical metadata. Missing gaps in the data set were filled using long term means as recommended by Jones et al.(1999) which altered the data set slightly, but means did not change. The study has revealed that maximum temperatures of the region are more variable compared to minimum temperatures. The mean trend in intra-annual variance is decreasing but not statistically significant. There is also evidence in data that warm spells vary per decade. Further analysis to identify abrupt changes can be done using other tests like isotonic regressions (Barlow and Brunk, 1972; Dykstra and Robertson, 1982), Csorgo and Horvath change point detection (Ferger, 1994; Habibi et al., 2005) and moving cut data detrended fluctuation analysis (He et al., 2012). The identification of long-term temperature trends will provide the Ugandan government with useful information. Since trends in temperature do exist, then government has to take proper actions to deal with the impacts of such 
trends on industry, fisheries, and agriculture. It also serves to fill the gap in the distribution of temperature trend analyses across the world.

\section{Acknowledgments}

We are grateful to Ingrid Booysen, Adebayo and Micheal Kizza for their inputs. Also our gratitude goes to the Center for Responsible leadership, University of Pretoria for their support.

\section{REFERENCES}

Aguilar E et al. (2005) Changes in precipitation and temperature extremes in Central America and northern South America,1961-2003. Journal of Geophysical Research.110: D23107, doi:10.1029/2005JD006119.

Anyah RO, Semazzi FHM. (2004) Simulation of the sensitivity of Lake Victoria basin climate to lake surface temperatures. Theor. Appl. Climatol.79: 55-69.

Anyah RO, Semazzi, F. (2009) Idealised simulation of hydrodynamic characteristics of Lake Victoria that potentially modulate regional climate. Int. J. Climatol. 29: 971-981.

Basalirwa CPK. (1995) Delineation of Uganda into climatological rainfall zones using the method of principal component analysis. Int. J. Climatol.15: 1161-1177.

Bodri L, Cermak V. (2003) High frequency variability in recent climate and the north Atlantic oscillation. Theor.Applied climatology. 74: 33-40.

Boko M. I. et al. (2007). Africa. Climate Change 2007: Impacts, Adaptation and Vulnerability. Contribution of Working Group II to the Fourth Assessment Report of the Intergovernmental Panel on Climate Change, M.L. Parry, O.F. Canziani, J.P. Palutikof, P.J. van der Linden and C.E. Hanson, Eds., Cambridge University Press. Cambridge UK, 433-467.

Braganza K, Karoly DJ, Arblaster JM. (2004) Diurnal temperature range as an index of global climate change during the twentieth century. Geophys. Res. Lett. 31: L13217, doi:10.1029/2004Glo19998.

Buishand TA. (1982) Some methods for testing the homogeneity of rainfall records. Journal of Hydrology. 58: 11- 27. 
Caloiero T, Coscarelli R, Ferrari E, Mancini M. (2005) Trend detection of annual and seasonal rainfall in Calabria (Southern Italy). Int. J. Climatol.31: 44-56.

CaprioJM, Quamme HA, Redmond KT. (2009) A statistical procedure to determine recent climate change of extreme daily meteorological data as applied at two locations in Northwestern North America. Climate Change.92: 65-81.

Chambers J, Cleveland W, Kleiner B, and Tukey P. (1983) Graphical Methods for Data Analysis, Wadsworth, in Engineering statistics Handbook. Published on line http://www.itl.nist.gov/div898/handbook/eda/section3/normprpl.htm.

Cheema M A, Farooq M, Ahmad R, and Munir H. 2006. Climatic trends in Faisalabad (Pakistan) over the last 60 years (1945 - 2004). Journal of Agriculture and Social Sciences. 1: 42- 45.

Co-operative Research Centre for Catchment Hydrology (CRCCH). (2005) TREND User Guide. $\mathrm{p} 17$.

de Lima MIP, Carvalho SCP, de Lima JLMP, Coelho MFES. (2010) Trends in precipitation: analysis of long annual and monthly time series from mainland Portugal. Advances in Geosciences. 25: 155 - 160.

Domroes M , El-Tantawi A. (2005) Recent temporal and spatial temperature changes in Egypt. Int. J. Climatol. 25: 51- 63.

Easterling DR, Alexander LV, Moksitt A, Detemmerman V. (2003) CCI/CLIVAR workshop to develop priority climate indices, Bulletin of the American Meteorological Society, 8: 1403-1407.

Easterling DR, Peterson TC and Karl TR. (1996) Notes and Correspondence on the development and use of homogenized climate datasets. Journal of climate.9: 1429- 1434.

Ghahraman B, Taghvaeian S. (2008) Investigation of Annual Rainfall Trends in Iran. J.Agric.Sci.Technol.10: 93-97.

Government of Uganda. (2002) The Initial National Communication of Uganda to the Conference of the Parties to the United Nations Framework Convention on Climate Change. Ministry of Water and Environment. Kampala.

Griffiths JF. (1972) Climates of Africa. World Survey of Climatology. Vol.10 Amsterdam. Elsevier. 
Hulme M, Doherty R, Ngara T, New M, and Lister D. (2001) African climate change: 1900-2100. Climate research 17:145 - 168.

IPCC. (2007) Climate Change 2007. The Physical Science Basis. Contribution of K.B. Averyt, M. Tignor and H.L. Miller, Eds., Cambridge University Press, Cambridge, 996 p. Jones PD, New M, Parker DE, Martin S, and Rigor IG. 1999. Surface air temperature and its changes over the past 150 years. Reviews of geophysics.37: 173-199.

Kaffle HK and Bruins HJ. (2009) Climatic trends in Israel 1970- 2002: warmer and increasing aridity inland. Climatic Change. 96: 63-77.

Kampata JM, Parida BP, Moalafhi DB. (2008) Trend analysis of rainfall in the headstreams of the Zambezi River Basin in Zambia. Physics and Chemistry of the Earth. 33: 621-625.

King'uyu SM, Ogallo LA, Anyamba EK. (2000) Recent Trends of Minimum and Maximum surface temperature over Eastern Africa Journal of climate 13: 2876-2886.

Kizza M, Rhode A, Xu Y C, Ntale H K, and Halldin S. (2009) Temporal rainfall variability in the Lake Victoria Basin in East Africa during the twentieth century Theoretical Applied Climatology 98: 119- 135.

Kruger AC, Shongwe S. (2004) Temperature trends in South Africa: 1960-2003. Int. J. Climatol.24: 1929-1945.

Longobardi A, Villani P. (2010) Trend analysis of annual and seasonal rainfall time series in the Mediterranean area. Int. J. Climatol. 30: 1538-1546.

Lopez-Moreno JI, Vicente-Serrano SM, Angulo-Martinez M, Begueria S, Kenawy A. (2010) Trends in daily precipitation on the northeastern Iberian peninsula, 1955-2006. Int. J. Climatol. 30: 1026 - 1041.

Lucio PS, Serrano, AI, Deus RJR. (2007) Statistical quality control for local-scale extreme temperatures. Case study: Lisbon, Portugal. Meteorological Applications.14: 275-290.

Mahe G, L'HoteY, OlivryJC, Wotling, G. (2001) Trends and discontinuities in regional rainfall of west and central Africa- 1951- 1989. Hydrol.Sci.J.46 (2): 211-226.

Mahli Y, Wright J. (2004) Spatial patterns and recent trends in the climate of tropical rainforest regions. Phil. Trans. R. Soc.Lond.B.359: 311-329. 
Micheals PJ, Balling Jr. RC, Vose RS, Knappenberger PC. (1998) Analysis of trends in the variability of daily and monthly historical temperature measurements. Climate Research. 10: 27-33.

Mubiru ND, Agona A, Komutunga E. (2009) Micro-level analysis of seasonal trends, farmers' perception of climate change and adaptation strategies in eastern Uganda. Seasonality revisited. International conference, institute of development studies, UK, 810 July, 2009.

National Environment Management Authority. (2008) State of environment report for Uganda. Kampala. Published on line www.nemaug.org/reports/2008.

New M et al. (2006) Evidence of trends in daily climate extremes over southern and West Africa. Journal of Geophysical Research. 111.

Nicholson S E. (1996) 'A Review of Climate Dynamics and Climate Variability in Eastern Africa', in Johnson, T. C. and Odada, E. (eds.), The Limnology, Climatology and Paleoclimatology of the East African Lakes, Gordon and Breach, Amsterdam, pp. 25-56. Ogallo LA. (1993) Dynamics of East African Climate. Proceedings Indian Academy of Sciences. Earth and Planetary sciences. 102(1): 203-217.

Oxfam. (2008) Turning up the Heat: Climate change and poverty in Uganda. Oxfam GB, Kampala.

Pandžić K and Lisko T. (2009) Homogeneity of average annual air temperature time series for Croatia. Int. J. Climatol. Published on line in Wiley Interscience. Doi:10.1002/joc..1922.

Peterson TC et al. (1998) Homogeneity adjustments of in situ atmospheric climate data: A review. Int. J. Climatol.18: 1493 - 1517.

Phillips J and Mcintyre B. (2000) Enso and inter-annual rainfall variability in Uganda: Implications for agricultural management. Int. J. Climatol.20:171-182.

Piccarreta M, Capolongo D, Boenzi F. (2004) Trend analysis of precipitation and drought in Basilicata from 1923 to 2000 within a southern Italy context. Int. J. Climatol. 24: 907922.

Rodhe H, Virji H. (1976) Trends and periodicities in east African rainfall data. Mon. Wea. Rev.104, 307-315. 
S.del Rio, Fraile R, Herrero L, Penas A. (2007) Analysis of recent trends in mean maximum and minimum temperatures in a region of the NW of Spain (Castilla y Leon). Theor.Appl.Climatol.90: 1- 12.

Sahin S, Cigizolu HK. (2010) Homogeneity analysis of Turkish meteorological data set. Hydrological processes. Published on line in Wiley Interscience, Doi:10.1002/hyp.7534. Samson HW. 1952. The trend of rainfall in east Africa. East African meteorological department. Serie paper.

Schreck C J, Semazzi H M. (2004) Variability of recent climate of Eastern Africa. Int. J. Climatol. 24: 681-701.

Stone DA, Weaver AJ. (2003) Factors contributing to diurnal temperature range trends in twentieth and twenty-first century simulation of CCCma-coupled model. Climate Dynamics. 20: 435 - 445.

Stooksbury DE, Idso CD, Hubbard KG. (1999) The effects of data gaps on the calculated monthly mean maximum and minimum temperatures in the continental United states. A spatial and temporal study. Journal of Climate. 12:1524-1533.

Thornton P. et al. (2007) Vulnerability, climate change and livestock research opportunities and challenges for poverty alleviation. Open Access Journal. 4(1): 1- 23.

Trenberth, K.E., P.D. Jones, P. Ambenje, R. Bojariu, D. Easterling, A. Klein Tank, D. Parker, F. Rahimzadeh, J.A. Renwick, M. Rusticucci, B. Soden and P. Zhai, 2007: Observations: Surface and Atmospheric Climate Change. In: Climate Change 2007: The Physical Science Basis. Contribution of Working Group I to the Fourth Assessment Report of the Intergovernmental Panel on Climate Change [Solomon, S., D. Qin, M. Manning, Z. Chen, M. Marquis, K.B. Averyt, M. Tignor and H.L. Miller (eds.)]. Cambridge University Press, Cambridge, United Kingdom and New York, NY, USA.

Wijngaard JB, Klein AMG, KÖnnen GP. (2003) Homogeneity of 20th century European daily temperature and precipitation series. Int. J. Climatol. 23: 679-692.

Zhang X et al. (2005) Trends in Middle East climate extreme indices from 1950 to 2003, J.Geophys.Res.,110,D22104,doi10.1029/2005JD006181. 